\title{
Mass Tort Litigation and the Seventh Amendment Reexamination Clause ${ }^{1}$
}

\author{
Patrick Woolley ${ }^{2}$
}

\section{Introduction}

The Seventh Amendment Reexamination Clause provides that "no fact tried by a jury, shall be otherwise re-examined in any Court of the United States, than according to the rules of the common law." [FN1] In 1995, Judge Richard Posner injected the Reexamination Clause into the mass tort debate in his decision in Rhone-Poulenc Rorer, Inc. [FN2] There, in the midst of a broad attack on the use of nationwide class suits, he argued that the Reexamination Clause imposes crippling limits on the use of bifurcation to resolve mass tort disputes. [FN3] Specifically, he argued that certification of an issue class [FN4] would lead to a risk of reexamination because one jury would decide whether the defendant was negligent and other juries would decide an overlapping issue - the allocation of fault between the defendant and a particular plaintiff. [FN5]

The argument against certification of issue classes based on the Reexamination Clause has emerged as a significant stumbling block to the aggtegate resolution of mass tort cases, [FN6] but it has received surprisingly little attention in the academic literature. While other aspects of Rhone-Poulenc have been the subject of vigorous criticism, [FN7] most critics in the academy and on the bench have not addressed the reexamination argument. [FN8] I do so in this paper and conclude that the Reexamination Clause should not pose a setious obstacle to the use of issue classes.

The argument that the Reexamination Clause limits the certification of issue classes is not new. The Fifth Circuit has long held that the Seventh Amendment prohibits the certification of an issue class if certification would result in the separate trial of overlapping issues. [FN9] The Manual for Complex Litigation and a number of coutrs besides the Seventh

\footnotetext{
1 Artigo originalmente publicado na lowa Law Review, n. 83, março de 1998, p. 499 e seg. Copyright (C) 1998 University of lowa (lowa Law Review); Patrick Woolley.

${ }^{2}$ Professor, The University of Texas School of Law. A.B. 1984, Stanford University; J.D. 1987, Yale Law School. I thank Douglas Laycock, Hans Baade, Michael Churgin, Michael Green, Samuel Issacharoff, Jack Ratliff, and Charles Silver who commented on earlier drafts of this paper. I also thank William Powers with whom 1 discussed certain aspects of the paper. Tim Chastain, Thomas Paxton, Scott Wheatley, and Rick King kindly provided substantial research assistance at various stages of this project.
} 
Circuit have apparently followed the Fifth Circuit's lead. [FN10] But the conclusion that the Reexamination Clause limits the use of issue classes is particularly troublesome when applied to the mass tort context, as Judge Posner did in Rhone-Poulenc.

While it is oftenpossible to adjudicate clains involvingmass economic haum withoutenyploying the issue class, this often cannot be done with mass torts, unless controversial aggregation techniques are used. [FN11] Mass economic harm cases-the cases in which the reexamination argument was developed - have been characterized as "upstrean cases() that is, cases where the harm is alleged to be some uniform course of conduct by the defendant, from which everything else follows." [FN12] In stark contrast, mass tort cases typicallyrequine that close attention be paid to the individual clams of plain tiffs at some stage of the litigation. Thus, efforts to certify classes to resolve mass tort claims in their entirety are often doomed because such suits would be unmanageable. If the parties and the couts are to enjoy the benefits of class aggregation in the mass tort context without sactificing the right to adjudicate individual issues, the availability of the issue class is essential. [FN13] Invocation of the Reexamination Clause to control the use of issue classes has the pernicious effect of shifting the class certification inquiry from a search for the fairest way of resolving a mass tort to a mechanical analysis that ignores the purposes of the Reexamination Clause. Thus, it is particularly iniportant to examine whether there is any basis for concluding that the Reexamination Clause imposes insuperable obstacles to the use of issue classes.

Iargue below that the Reexamination Clause imposes no such obstacles. I do not contend that the use of issue classes is always constitutional. I agree that bifurcation violates the Seventh Amendment whenever it leads to "confusion and uncertainty" [FN14] a possibility that should be considered case-bycase before overlapping issues are separated for trial. Nor do I argue that bifurcation of overlapping issues is desirable in every case in which ir would not lead to confusion and uncertainty. I simply reject the view that the Reexamination Clauseimposes an inflexible tule forbidding the separate nial of overlapping issues.

I make my argument in two parts. In Part. II, I discuss the appropriate framework for interpreting the Reexamination Clause. Then, in Part II, I consider Rhone-Poulenc and the Fifth Circuit's recent decision in Castanov. American Tobacco Co. [FN15] I argue that neither a sound understanding of the Reexamination Clause nor Supreme Court precedent supports the Fifth and Seventh Circuits' analyses.

\section{Interpreting the Reexamination Clause}

\section{A. The Traditional and Modem Interpretations of the Clause}

The traditional view has been that the Reexanination Clause should be read statically, [FN16] that is, to constitutionalize those rules of reexamination bequeathed by the English common law of 1791 , [FN17] except for those rules deemed rules of "form." [FN18] Those holding the traditional view tend to adhere closely to the rules of English common law of 1791 and are reluctant to treat the Englishrules as mere rules of form. By contrast, those holding the modern view argue that the Reexamination Clause should be read in a more open-ended fashion. [FN19] While recognizing the distinction between rules 
of "substance" and nules of "form," adherents of the modern view have tended to regard specific English common-law rules as matters of form not binding on modern courts.

The choice between the static and dynamic approaches bearson the pemissibility of bifurcaring overlapping issues. For reasons discussed below, the rule set forth in Rhone-Poulenc and Castano cannot be premised on the English commonlaw of 1791. [FN20] Thus, if the Reexamination Clause mustread statically, Rhone-Poulenc and Castano are clearly wrong.

The traditional view was mostempharically stated by the Supreme Court in Dimick v.Schied, acase that construed the Seventh Amendment as a whole. [FN21] There, the respondent argued that a procedural device knownas additur was unconstitutional because it was unknown at common law in 1791. [FN22] The Court closely examined the old English cases to detemine whether the cases authorizedadditur. Concluding that the cases did not, the Court found additur unconstitutional. Faced with the argument that common-lawnules could evolveover time, the Courtheld, over a vigorous dissent by Justice Stone, that the Seventh Amendment adopted the rules of common law in force in 1791. [FN23] In rejecting the possibility that the common law referred to in the Amendment was "susceprible of grow th and adaptation to new circumstances," the Court did not attempt to understand how the Founding Fathers conceived of the rules of common law Rather, it simply reasoned that " $t$ ) o effectuate any change in these rules is not to deal with the conmon law, qua common law, but to alter the Constitution." [FN24]

Despite Dimick's emphatic language, the Count has moved beyond the static test in defining the constirutionally protected boundaries of the jury's province under the Seventh Amendment Trial-byJury Clause. [FN25] Indeed, there appears to be no principled way to return to the static test without radically altering the terrain of federal civil litigation. The static approach, for example, camotexplain the Court's approval of modem procedural devices that allow the courts to deternine sufficiency of evidence. [FN26] If summary judgment and directed verdictare considered mere matters of "form," even though they greatly affect the substantive power enjoyed by a jury vis-à-vis the federaljudiciary, then manyother issuesmust also involve mere matters of form. [FN27] Thus, unless the Court is prepared to forbid the use of summaryjudgment or directed verdict, there is no principled basis for concluding that the Trial-by-Jury Clausc incorporates the English common law of jury trial procedure.

At least until the Court's recent decision in Gasperini v. Center for Humanities, [FN28] however, it was unclear whether the Court would continue to apply the static approach exemplified in Dimick to questions under the Reexamination Clause. This uncertainty resulted in part from suggestions by the Court that the static interpretation of the Reexamination Clause remained good law, even as the static approach became obsolete for some issues under the Tria-by-Jury Clause. In Colgrovev. Battin, [FN29] for example, the Court concluded that the Framers did not intend to "equate the constitutional and common-law charactenistics of the jury," [FN30] but suggested in dicta that the Reexamination Clause would be interpreted differently. [FN31] 
The Cout resolved the uncertainty by rejecting a static approach to the Reexamination Clause in Gasperini. [FN32] In an opinion expressly inviting reconsideration of Dinick, the majority rejected bondage to the common-law rules of 1791. [FN33] Justice Ginsburg, writing for the Court, dismissed in a footnote the dissent's argument that the Reexamination Clause should be interpreted statically:

If the meaning of the Seventh Amendment were fixed at 1791, our civil juries would remain, as they unquestionably were at common law, "twelve good men and true... ." Procedures we have regarded as compatible with the Seventh Amendment, al though not in conformity with practice at commonlaw when the Amendment was adopted, include new trials restricted to the determination of damages... and Federal Rule of Civil Procedure 50(b)'s motion for judgmentas a matter of law. [FN34]

The Court's analysis is significant in two respects. First, the Court relied on the dynamic interpretation it had previously given to the Trial-by-Jury Clause to support its interpretation of the Reexamination Clause. In so doing, the Courtendorsed the view that the same interpretive approach should be applied to both Clauses of the Seventh Amendment, thereby rejecting the dissent's argument that the Reexamination Clause was more susceptible to a static interpretation than the Trial-by-Jury Clause. [FN35] Second, the Court did not even bother to consider whether the practice at issue in Gasperini was consistent with the form or detail of English practice in 1791. The Court's silence on this question is particularly conspicuous in view of the vigorous historical debate between Justice Stevens, who agreed with the Court on the Reexamination issue, and Justice Scalia, who disagreed. [FN36] The majority's refusal to address history presumably does not mean that history is irrelevant to the interpretation of the Clause. [FN37] Rather, the Courtappears to have concluded that any historical practice that stands in the way of some type of appellate review of damage awards must give way in the interests of the "fair administration of justice." [FN38] Inshor, Gasperinirequires adynamic interpretation of the Reexamination Clause.

In his dissent, Justice Scalia argued that "the content of (the common law) was familiar and fixed" [FN39] in 1791 and complained that the Cout "abandon(ed) any pretense at faithfulness to the commonlaw." [FN40] As I discuss in Parts B and Cbelow, however, the historical evidence in fact casts doubt on the proposition that the Founders specifically intended the reference to the common law to freeze the Clause in time. Thus, there is no reason to insist upon a static reading of the Reexamination Clause.

\section{B. The Purposes of the Reexamination Clause}

\section{The Constitution of 1787}

The original Constitution did not expressly guarantee ajury trial in civil actions. Indeed, Article III of the Constitution appeared to leave open the possibility that facts could be retried by the Supreme Court sitting without a jury. This is because Article III, Section 2 gave the Supreme Court "appellate 
Jurisdiction, both as to Lawand Fact" [FN41] "This grantof power sounds innocuous to a modemear, but as Professor Wilfred Rirz has noted,

(c) he "appeal" was the method of supetior court review in civil-law jurisdictions, jurisdictions that did not use the jury (such as admiralty). An appeal would, in such a system, open the way to a consideration of the whole case by the superior court. An appeal might have been taken either before or after an initial trial in the inferior court. When it was taken after the initial trial the result is that there was a second trial, de novo, in the superior court. On appeals both facts and law were open for consideration, either as an initial propasition or by reconsideration. [FN42]

This form of appeal was not limited solely to civil law jurisdictions. At the time the Constitution was ratified, a statutory appeal in the New England states permitted removal of a case after judgment for a retrial by jury in a superior court. [FN43] Article III, Section 2 of the Constitution arguably authorized similar retials in federal court. Indeed, because the original Constitution did nothave an express civiljury trial provision, Section 2 of the Judicial Article could faily be read as authorizing the Supreme Court to reny civil cases without ajury. In fact, Professor Wythe Holt has argued that the Framers intended such areading. [FN44]

\section{The Concems of the Anti-Federalists}

Whatever the original intent of the Framers, it became clear duning the ratification debates that the right to jury trial would have to he protected. [FN45] As the historian Jack Rakove has noted, the Anti-Federalists, who were opposed to the ratification of the Constitution altogether, attained as great a consensus on the threat posed by Article III to jury trial as they found on any other issue. [FN46] Some Anti-Federalists went so far as to argue that the Constitution abolished the civil jury trial. [FN47] in response, Federalists gave assurances that Congress could protect the right to a jury trial. Alexander Hamilton, for example, wote:

If ... the reexamination of a fact once determined by a jury, should in any case be admitted under the proposed Constitution, it may he so regulated as to be done by a second jury, either by remanding the cause to the court below for a second trial of the fact, or by directing an issue immediately out of the Supreme Court.

But it does not follow that the reëxamination of a fact once ascertained by a jury, will be permitted in the Supreme Court....

... The legislature of the United States would certainly have full power toprovide, that in appeals to the Supreme Cout there should be no reëxamination of facts where they had been tried in theoriginal causes byjuries. [FN48] 

[FN49]

These assurances, however, did notlessen the call by Anti-Federaliss for constitutional guarantees.

The alarm of the Anti-Federalists was not linited to concenn that jury trials might be abolished altogether:"The Supreme Court's appellate authority over law and fact remained unacceptable to AntiFederalists even if reutials in the Supreme Court were byjury. Anti-Federalists cherished juries in large part because of the protection they provided against central authority. [FN50] Trial by jury in the Supreme Court would vitiate that protection. Under such ascheme, final authority to render verdicts would shift fromlocal juries to District of Columbia juries sympathetic to federal authority and detached from local concerns.

The perceived need for protection against central authority had an intensely practical as well as an ideological dimension Anti-Federalists feared the federal courts would oppress local debrors on behalf of out-of-state credirors. [FN51] The fact that retrials on appeal in the Supreme Court might be byjury provided little comfort. As Professor Wolfram has explained, "the lastresort for the hounded debror was a hopefully sympathetic jury in his local federalcourt." [FN52] Inaddition, Anti-Federalists wereconcemed about the cost of retrying cases in the capital. [FN53] For these reasons, the Anti-Federalists sought not only to preserve the right to jury trial, bur to ensure that no retrials whatsoever would take place in the Supreme Court.

While the Anti-Federalists were unsuccessful in preventing the ratification of the Constitution, the Seventh Amendment was promplyadded to the Constitution in 1791. The "Iegislative history" of the Clause is sparse, [FN54] but there is no doubt that the concerns of the Anti-Federalists were addressed by the Reexamination Clause. The Clause provides that "no fact tried by a jury, shall otherwise be reexamined in any Court of the United States, than according to the rules of common law." [FN55] The rules of common law in effect in 1791 clearly prohibited tertials de novo on appeal. [FN56]

\section{The Argument for a Dynamic Reading of the Clause}

If the Reexamination Clause simply forbade de novo review of facts tried by ajury, the Clause would have little relevance to modem civil procedure. Noone argues today that findings of fact by a jury should be subject to de novoreview on appeal. The Clause remains important because its text, specifically it incomporation of the "nules of common law," arguably sweeps more broadly than the reasons for which the Clause was ratified. Put another way, the text of the Reexamination Clause has the potential to constitutionalize vast areas of civil procedure, including the law of preclusion. For that reason, it is critically important to deternine whether the reference to "common law" in the Clause should be read starically or dynamically.

In Gasperini, Justice Scalia reljed on Dimick and Justice Story's opinion in Unired States v. Wonson [FN57] to support his view that the Reexamination Clause should be interpreted statically. [FN58] Neither case, however, provides firm support for Justice Scalia's argument. Dimick, for example, 
stated that all of the Seventh Amendment must be given astatic interpretation. [FN59] Thatdicum, of course, is no longer good law. The Court no longer insists on a static interpretation of the Trial-by-Jury Clause. [FN60] Wonson is similarly unhelpful. Justice Scalia quoted Wonson's conclusion that "the common law here alluded to $\ldots$ is the common law of England" to support his view that the rules of common law have a fixed historical meaning. [FN 61] Justice Scalia, however, misunderstood Justice Story's point: The Reexamination Clause did not incorporate the common law of the particular state in which the federal court happened to sit, but a more general common law. [FN62] While Wonson went on to proclaim that "the invariable usage settled by the decisions of ages" prohibited the court from reexamining the jury verdict, $[\mathrm{FN} 63]$ there is nothing in the opinion stating that the rules of common law cannot be modified, if necessary. The case simplyestablished that the reference to "common law" in the Clause points the federal courts to a single source of law, the common law of England, which as I discuss below was subject to modification in light of local conditions. [FN64]

The conclusion that this static approach best accords with the Founders' understanding of the common law, however, does have some historical support. While not addressing the reexamination question, the distinguished legal historian Morton Horwitz has argued that

(t) he (Revolutionary Generation) had little difficulty in conceiving of the common law as a known and determinate body of legal doctrine....

... The persistent appeals to the common law in the constitucional struggles leading up to the American Revolurion "created a regard for its virtues that scems almostmystical." As a result, by the end of the eighteenth century, lawyers regarded the "concept of the common law as a body of principles," which "encouraged uninhibited use of English precedents by the legal profession in the federal courts." [FN65]

But the static approach oversimplifies the Founding Generation's understanding of conmon. law in an important way. The Founders understood that the common law of England had not been imported whole into the United States. [PN66] That is not to say that the Founders believed commonlaw principles to be malleable. It was not the principles of common law that had changed, [FN67] but the applicability of those principles in light of local conditions. As Senator Oliver Ellsworth stated during the secret Senate debates on the Judiciary Act of 1789, "The Common Law of England in some Instances (has been) found inapplicable to the Circumstances of some of the States." [FN68]

This understanding found support in the influential work of William Blackstone. [FN69] Blackstone recognized that were the common law applicable to the Colonies, it could not be uniformly applied there and in England because the local conditions were different. [FN70]

It is nota great leap from the conclusion that the English common law could not be fully applied in the United States to the conclusion that the common law should evolve over time to reflect local conditions. To be sure, there may have been a consensus at the time the Seventh Amendment was written that the underlying principles of common law that were applicable in America were timeless. 
[FN71] Buteven if this consensus existed, itmay have no bearing on whether limits on reexamination were understood to be subject to evolution. [FN72]

There is reason to believe that some in the Founding Generation understood, at least as a descriptive matter, that the rules if not the principles of common law had evolved over time. [FN73] The Founding Generation was familiar with Blackstone, whose influential Commentaries recognized that the common law had changed over time, [FN74] and with Lord Mansfield, whowas contemporaneousty engaged in common-law reform as Lord Chief Justice of the King's Bench between 1756 and 1788. [FN75] Some in the Founding Generation clearly welcomed the possibility of evolution. Justice ]ames Wilson, for example, once charged a jury that " $(t)$ he expanding and accommodating genius of the common law" permits the courts to apply "easily and aptly its maxims and rules... in new situations and emergencies." [FN76] Others despised the evolutionary potential of the common law. Thomas Jefferson, for example, bitterly criticized Lord Mansfield: "While the object of former judges ha(d) been to render the law more \& more certain,' Jefferson wrote in 1785, Mansfield had sought 'to render itmore uncertain underpretense ofrendeting it more reasonable." [FN77] Implicit in Jefferson's disapproval, however, was a recognition that the common law had changed under Lord Mansfield. Indeed, Jefferson recognized that judges had overturned "settled rules" of common law in previous historical periods as well. [FN.78]

Despite the evidence that some members of the Founding Generation understood that the rules of common law changed over time, the extent to which this understanding was widely shared and consciously acted upon by the Framers of the Reexamination Clause, is unclear. We have almostno direct evidence of the Framers' intent. [FN79] Itseems hard to believe, however, that those who framed the Seventh Amendment were unaware that therules of common-law procedure had undergone significant change in England. Had they intended to rule out the possibility that the rules of reexamination would change over time, it is difficult to understand why they would have incorporated the "rules of common law," when those rules had proven malleable over time.

Thene were other ways the Clause could have been drafted. The evolutionary potential of the commonlaw, for example, could have been cabined through codification. [FN80] The Reexamination Clause could have been drafted to require, for example, that appellate review of suits at common law proceed only by wit of error. [FN81] Alternatively, it would have been easy to refer explicitly to those common-law rules in force at the time of ratification. [FN82] This latter option would have made clear the Framers' intent to freeze the rules of reexamination. The Framers chose neither approach. Thus, the verystructure of the Reexamination Clause suggests the possibility that the Framers intended to permit furthercommon-law development.

The Anti-Federalists may well have preferred to disable the courts as well as Congress from varying the rules of reexamination. Because the Federalists were "solidly" in control of the First Congress, [FN83] however, Anti-Federalists were in no position to impose their will. [FN84] By receiving the English common-law rules of reexamination, the Framers may have addressed the biggest fear of the AntiFederalists (the concemover legislative abuse), [FN85] while intentionally keeping alive the judiciary's ability to adjust the rules of reexamination over time, if necessary. 
While it is impossible to know for sute what the Framers intended, the above analysis suggests that there is no basis for confidence that the Reexamination Clause is more susceptible to a static reading than the Trial-by-Jury Clause. In the absence of such evidence, it makes sense to read the Clauses together because in some respects the Clauses are two sides of the same coin. The Trial-by-jury Clause protects the jury's decisionmaking authority vis-à-vis the courts before a verdict is rendered. The Reexamination Clause protects the jury's decision after it has been rendered. Indeed, although the presence of both Clauses in the Constitution has obscured the point, the Trial-by-Jury Clause is sufficiently broad to provide protection against any reexamination that would usurp the province of the jury. [FN86] For these reasons, it would make littlesense to read the Reexamination Clatse more restrictively than the Trial-by-Jury Clause. Because it is settled that the right to ajury trial does not require a trial in accordance with common-law rules of civil procedure in effect in 1791, [FN87] the Reexamination Clause similarly should not be read to require review of jury verdicts in accordance with the common-law rules of 1791 .

\section{Applying the Dynamic Approach}

There are two different ways the Reexamination Clause can be read dynamically. Fitst, the Clause might be read to do no more than establish ajurisdictional principle, that is to reserve wo the federal couts alone-as opposed to Congress-the power to set the rules of reexamination. Under this view, the Clause would have no bearing on the content of the rules themselves. While this reading arguably conforms to the text of the Clause, it has no support in eithercaselaw or history. Gasperini leaves no doubt that the Supreme Courtbelieves that the Clause imposes limitson the courts as well as Congress. [FN88] Moreover, the controversy that led to ratification of the Reexamination Clause was precipitated by concen over the possibility that the courts would have the power to reny de novo cases on appeal, a substantive rather than ajurisdictional issue. [FN89] Anyinterpretarion that would treat the Reexamination Clause as purelyjurisdictional would fail to givesufficient weight to the substantive nature of the Founding Generation'sconcerns.

For thesereasons, the Reexamination Clause is best understood as a source of authority for courts to articulate those norms concerning teexamination that are sufficien ty fundamental tooverride contrary considerations. [FN90] In articulating such noms, courts must give due consideration to history, butneed not attempt to replicate rigidly the balance of power that existed between local juries and the federal judiciary in 1791. [FN91]

\section{The Issue Class and the Reexamination Clause}

In this Part, I analyze whether the separate trial of overlapping issues by different juries is consistent with a dynamic reading of the Clause. I conclude that the Reexamination Clause-read properly — does not forbid the separare trial of overtapping issues. 


\section{A. Rhone-Poulenc and Castano}

A number of cours have applied the Reexamination Clause to deternine whether issues may be separated for trial before different juries. [FN92] I focus on the Seventh Circuit's decision in RhonePoulenc and the Fifth Circuit's decision in Castano because they provide the most comprehensive explanation available of this approach. [FN93]

In Rhone-Poulenc a nationwide class of hemophiliacs infected withHTV sued drugcompanies on the ground that the companies negligently had failed to guard against the possibility that blood solids manufactured by the companies had been contaminated with HIV. [FN94] The district court certified an issue class to detemine whether the companies had been negligent. [FN95] It was contemplated that if the companies were found negligent in the class trial, the negligence finding would be used as an estoppel in the individual suits that would address anyother relevant issues. [FN96]

The Seventh Circuit granted a wit of mandamus ordering the district court to decertify the class, in part because the court concluded that the bifurcation plan violated the Reexamination Clause. Judge Posner, writing for a panel of the court, held that a trial judge

must not divide issues between separate trials in such a way that the same issue is reexamined by different juries... The right to ajury trial in federal civil cases, conferred by the Seventh Amendment, is a right to have juriable issues determined by the furst jury impaneled to hear them (provided there are no errors warranting a new trial) and not reexamined by another finder of fact. [FN97]

Because the issue of defendant's negligence overlapped with the issue of comparative negligence, the court concluded that the bifurcation plan was "inconsistent with the principle that the findings of one jury are not to be reexamined by a second or third or nthijtry." [FN98] The cour expressed concernover the possibility that later juries might consider the same facts as the firstjury butreach different conclusions. "How the resulting inconsistency between juries could be prevented," the court complained, "escapes us." [FN99]

The court'sconclusion that negligence and comparative negligence issues inevitably overlap is undeniable, at leastas a theoretical matter. [FN100] Juries deciding comparativenegligence are pernitted to consider the seriousness of defendants' conduct. [FN101] Because the egregiousness of defendants' conduct often carnot properly be evaluated on the basis of a special verdict tendered by an earlier jury, a later jury considering comparative negligence probably would have to hear evidence of defendant's negligence. [FN102] For that reason, when separate juries try the issues of negligence and comparative negligence, overlap between the issues will often be inevitable. [FN103] Put another way, negligence is a "crossover" issue--an issue on which evidence will have to be presented in both phases of a bifurcated proceeding. [FN104] Thus, there is noquestion that urials of negligence and comparative negligence issues to separate juries will violate the legal standardenunciated by the Seventh Circuit.

The Fifth Circuit similarly has concluded that separate trials of negligence and comparative negligence violate the Reexamination Clause. In Castano, the Fifth Circuit ordened decertification of a 
nationwide class suit againstcigarette manufacturers, in part on the ground that severing the issue of the manufacturers'negtigence fron the comparativenedigence of the smokers would violate the Reexamination Clause. [FN105] Quoting the Reexamination Clause in support, the Fifth Circuit held that

(t) he Seventh Amendment entitles parties to have fact issues decided by one jury, and prohibits a second jury from reexamining those facts and issues. Thus, (the) Constiution allows bifurcation of issues that are so separable that the second jurywill not be called upon to reconsider findings of fact by the first.... [FN106]

The cout concluded that severing the manufacurers' negligence from the issue of comparative negligence would create an unacceptable risk of reexamination:

There is a risk that in apportioning fault, the second jury could reevaluate the defendant's rault, determine that the defendant was not at fault, and apportion $100 \%$ of the fault to the plaintiff. In such a situation, the second jury would be impermissibly reconsidering the findings of a firstjury. [FN107]

Whilesome of Castano's language may be read tosuggest that the risk of reexamination simply creates an obstacle to satisfying the requirements of Rule 23 of the Federal Rules of Civil Procedure, [FN108] the opinion as a whole supports Rhone-Poulenc's conclusion that the very act of bifurcating overlappingissues may, by itself, violate the Reexamination Clause. [FN109]

Rhone-Poulenc and Castano state that the Seventh Amendment prohibits a second jury from "reexamin (ing)" [FN110] or "reconsidering" [FN111] a factual issue alteady decided by another jury. Although these tems are somewhat ambiguous, [FN112] an earlier Fifth Circuit decisionstated that the right involved is the right to have only one jury "decide" an issue of fact. [FN113] This right could be understood to forbid a court from giving effect to findings of a later jury that are inconsistent with those of an earlier jury, an application of preclusion law. [FN114] Yet, the Fifth and Seventh Circuits go further by forbidding the very use of bifurcation in certaincircumstances.

Because the Fifth and Seventh Circuits' discussions of the Reexamination Clause are remarkably sketchy, the underlying justification for the courts' constitutional holding is far from clear. One possible reading of the decisions is that the Reexamination Clause prohibits a trial structure thatcreates a risk that differentjurieswill render inconsistent findings. [FN115] This readingin effect would broadensignificantly the law of preclusion in the bifurcation context. Predusion law traditionally presumes ajury will follow instructions to give the findings of an earlier jury preclusive effect and provides a remedy only if the jury fails to do so.

Asecond possible reading of the Fifth and Seventh Cicuit decisions would treat the prohibition against "reexamining" or "reconsidering" facts found by an earlier jury as intended to provide protection against more than inconsistent findings. "The quoted terms are broad enough to prevent a simple inquiry into an issue decided by an earlier jury, even if the purpose of the inquiry is not to confirm or reject the earlier finding. [FN116] If, for example, the issues of negligence and comparative negligence are separated, alater juy deciding the issue of comparative negigence would be unable to do so without also teexamining-that is, inquiringinto-the negligence of the defendant. [FN117] This sort of reexamination of the same 
issue is arguably unfair in two separate ways. First, the later jury may decide the case in a manner that is inconsistent with the undisclosedreasoning of the first jury. Second, the need to re-present evidence on the same issue in both parts of a bifurcated proceedingarguably imposes a constitutionally unteasonable burden on the parties.

Although it is hard to imagine a situation in which the two readings of the Clause sketched above would point in different directions, the concems of the rationales are distinct. The first focuses on the traditional concem of predusion law: ensumg that the authoritative findings of anearlier decisionmaker are applied in later litigation. The second focuses instead on the apparent unfaimess of multiple hearings on the same issue.

Neither rationale is premised on the English common law of 1791, nor could they be. The common law imposed rules of predusion, but the Fifth and Seventh Circuits' analyses go beyond traditional predusion doctrine. Nor can justification for going beyond traditional preclusion doctrine be found by examining bifurcation atcommon law. Bifurcation as we know it today was virtually unknown at commonlaw. [FN118] To ask how the Englishcommon law in 1791 might have addressed the problem of overlapping issues in bifurcated suits is to pose an unanswerable question. The Fifth and Seventh Circuits wisely have made no effort to ask or to answer this question, implicitly relying instead on a dynamic reading of the Clause.

It is from that dynamic perspective that I consider in Parts BandC below the rationales for the Fifth and Seventh Circuits' analyses and conclude that neither rationale can withstand scutiny. Finally, in Part D, I analyze whether Gasoline Products Co, v. Champlin RefiningCo., [FN1119] the Supreme Court case on which the Fifth and Seventh Circuits rely, supports their conclusion that separate trials of overlapping issues are impermissible. Iconclude that Gasoline Products applies an approach far more liberal than that of the Fifth and Seventh Circuit.

\section{B. The Predusion Rationale}

\section{The Role of Preclusion Docaine}

The conclusion that predusion doctuine is relevant to the Reexamination Clause is supported by the text, which provides that "no fact tried by ajury, shall be otherwise re-examined in any Court of the United States, than according to the rules of common law." [FN120] In other words, the text of the Clause appears to sweep within its jurisdiction all nules of reexamination applicable to facts tried by ajury, including the rules of preclusion.

Because the history and application of the Clause has al most always been focused on limiting judicial power to review verdicts through past trial motions and appeal, the conclusion that precl usion doctrine falls within the Clause may initially appear implausible, notwithstanding the literal wording of the 
text. Indeed, the Clause is so pervasively associated with the problem of verdict review that it generally doesnot even figure in discussions of the constitutional bases of preclusion law. [FN121]

There can be no question, however, that the Reexamination Clause must constitutionalize somerules of preclusion if it is not to be rendered toothless. It is easy to overlook this point because modem daypreclusionnules sweep far more broadly than the Constitution requires. In the absence of aconstitutional floor, however, the law of preclusion could be rewritten to permit a losing party to circumvent linits on appellate or trial court review by filing another lawsuit. [FN122] For that reason, the Reexamination Clause must be read to mandate those predusion rules necessary to avoidevasion of limits on the review of verdicts.

The rules of direct estoppel fit this description. The rules are designed to prevent a party from relitigating facts decided between the same parties on the same cause of action. [FN123] Inother words, the rules of directestoppel provide a minimum level of preclusion below which the federal procedural system may not fall without running afoul of the Reexamination Clause. For that reason, difectestoppel rules have consritutional stature.

Because claim preclusion typically sweeps far mote broadly than directestoppel, there is rarely a need to apply the rules of directestoppel. [FN124] Thus, the Reexamination Clause typically lurks in the background when preclusion issues arise. The rules of claim preclusion are not always applicable in the bifurcation context, however. Take, for example, a bifurcated case in which the defendant loses the liability phase. Because there is no final judgment on the claim as a whole, it is direct estoppel rather than claim preclusion that would forbid relitigation of the liability issue. [FN125] In the absence of directestoppel rules in this context, a later jury could, without violating any legal obligations, tum the second stage of the bifurcated proceeding into the functional equivalent of a retrial de novo of the liability issue. For that teason, there can be no question that the Reexamination Clatse mandates application of direct estoppel rules againsta defendant who loses in the first stage of a bifurcated proceeding. [FN126]

\section{The Unwarranted Extension of Preclusion Doctrine}

Rhone-Poulenc and Castano may be read to express concem that bifurcation of overlapping issues improperly affects the finality of jury decisions. When, for example, separate trials of negigence and comparative negligence are permitted, the jury deciding comparative negligence must hear evidence of defendant's negligence to render a proper decision. Providingsudh evidence, however, creates a risk that thelater jury will fail tocredit the negligence finding of the earlierjury. One way toprevent this sort of jury misconduct is to forbid the use of bifurcation when separate juties would need to hear evidence on the "same issue." Under this reading of the Fifth and Seventh Circuirs' decisions, negligence and comparative negligence could not be tried separately because both juries would hear evidence on the same issuenegligence. [FN127] 
This reading would represent an extrardinary extension of preclusion law. We do notnomally require that a party be protected against an amomphous risk that astate actor - in this case the jury-will violate its legal obligations. [FN128] Preclusion law is noexception in this respect. The predusive effect of factual findings typically is ensured by instructing the second jury that it must accept the findings of an earlier jury on a decided issue. A remedy is provided only if the jury clearly fails todo so. [FN129]

It might be argued that the structural protection provided by the Fifthand Seventh Circuit is appropriate in the bifurcation context. When a jury fails to give preclusive effect to an earlier finding in a bifurcated proceeding, a policy against reexamination embedded in the Constitution as well as in the ordinary law of preclusionis implicated. [FN130] This argument cannot withstand scrutiny, however. It assumes that a laterjurycannot be trusted to give preclusive effect to the findings of an earlier jury, but no basis for this assumption exists. If the first jury renders a sufficiently detailed verdict, later juries can be instructed to apply the first jury's findings. Assume, for example, that the plaintiffs in Rhone-Poulenc had prevailed on what Judge Posner dismissively called the "serendipity theory" [FN131] of negligence. A later jury then could have been instucted that by failing to take appropriate precautions against the contamination of blood products with Hepatitis $B$, defendanss were legally responsible for the HIV contamination. [FN132] Assuming that the evidence of defendant'snegligence is presented again to allow the jury to apportion fault between the parties, [FN133] it is hard to see why such an instruction would receive any less respect from a jury than any oher instruction by the court. [FN134] Indeed, the instruction is more likely to be followed than manyother instuctions. To begin with, the instructionshould be easier to understand and apply than instructions that set forth abstract standards of law. [FN135] Moreover, an instruction characterizing the relevant facts is likely to be well-received by jurors because it makes their task significantly easier.

In any event, the law presumes almost without exception that a jury will follow its instructions. [FN136] The minimal risk of inconsistent findings between different stages of bifurcated proceedings clearly does not overcome the weight traditionally given to this presumption. In Richardson v. Marsh, [FN137] the Court indicated that the presumption could be overcome only when "'the risk that the jury will not, or cannot, follow instructions is sogreat and the consequences of failure so vital to the defendant; that the practical and human limitations of the jury system cannotbe ignored." [FN138] The Courthas found these requirements to be satisfied in only two narrowly drawn circumstances. [FN139] Each involved a criminal prosecution, in which the stakes for a defendant are high. Moreover, each of the cases in which an exception to the presumption was recognized involved instances in which the court asked a jury to ignore damaging information it had received about a criminal defendant. [FN140] By contrast, there is no reason to believe that a jury would have difficulty crediting the findings of an earlier jury. [FN141]

Indeed, this presumption has been applied in comparative negligence cases brought in state courts in situations when it would be far more difficult for a juror to comply with such instructions than in the bifurcation context. Several state couts, for example, have expressed confidence chat, in deciding comparative negligence, a juror can faithfully apply a previous finding that defendant was negligent even when the juror dissented from the negligence finding. [FN142] In shont, the risk of inconsistent findings 
does not justify the Fifth and Seventh Circuits' refusal to permit the separate trial of ovetlapping issues. [FN143]

\section{C.'The Nonpreclusion Rationales}

\section{The Risk of Inconsistency}

The risk of inconsistencyis not limited to the possibility that later juries will not be faithful to the findings of the first jury. Even if we could be certain that a later jury would follow its instuctions, arisk of inconsistency between juries would exist withrespect to matters on which the firstjury did not disclose its reasoning. If the first jury were to find a defendant negligent without specifying the reasoning on which it relied, a later jury might rely on differentreasoning in allocating fault between the parties. For example, ajury that finds a defendant negligent based on the view that the defendant was going one mile over the speed limit might allocate fault very differently from a jury that believes the defendant was going twenty miles over the speed limit. Thus, differences in the way in which juries understand the same case may have a material effecton the outcome of the case, even iflaterjuries give praclusive effect to the findings of the first jury.

This sort of inconsistency does not trigger the Reexamination Clause, however: As I discuss above, the primary purpase of the Clause was to linitreview ofjuryverdicts. This purpose can be achieved in the bifurcation context by requiring that the formal findings of a jury be given estoppel effect. Provided later juries respect the rules of directestoppel, the second phase of a bifurcated proceeding cannot be used to evade limits on review. If, for example, later juries respect their obligarion to give preclusiveeffect to a class jury's finding that a defendant was negligent, bifurcation cannot give the defendant an opportunity to obtain review of the class verdict by a later jury.

The fact that the class jury may think the defendant was very negligent and later juries may think the defendant was only slightly negligent changes nothing. This is because the review process is focused solely on the formal findings of a jury. A court reviewing ajury verdict through posttrial motions or on appeal asks whether, under the relevant standard of review, there is enoughevidence in the record tosupport the jury's findings. How the jury actuallyreasoned its wray to a finding typically is of norelevance to the decision and, indeed, is protected from disclosure in mostcases by Federal Rule of Evidence 606 (b). [FN144] For these reasons, it is fully consistent with limitations on the review of verdicts for a second jury in a bifurcated proceeding to do no more than apply the formal findings of the first jury.

This conclusionmaynotbe dispositive, however. While the primatypurpose of the Reexamination. Clause is to limit review of jury verdicts, the Supreme Court has construed the Clause somewhat more broadly. The Court has stated that the Clause should be construed to prevent an "inditect impairment" of the right to a jury trial. [FN145] Thus, to the extent that a second jury's reexamination of facts would impair the right to a jury trial, the Reexamination Clause arguably has been violated. 
If the constitutional right to a trial byjury means the right to a verdictbased on the unanimous reasoning of the jury, bifurcation of overlapping issues would impair the right to ajury trial whenever the first jury's conclusions on material facts were not disclosed. [FN 146] When the first jury does not disclose its reasoning process, there is no guarantee that a later jury will apply the same reasoning to the facts of the case.

It is hard to see, however, why a defendant should escape liability when all the members of the jury agree that the defendant is liable. [FN147] Because the primary function of the civil jury is to assess liability rather than tell a story, such a rule would seem to lose the forest for the rrees. [FN148] Although a number of state courtshave concluded that unanimity as toreasoning is notrequired, [FN149] there is a dearth of federal authority on the issue. What little federal authority exists, however; supports the common-sense view that as long as the jury agrees on the findings that it is asked to make, each juror may agree to the findings for different reasons. In Schad v. Arizona, [FN150] for example, a plurality of the Courtendorsed the view that incriminal cases, "as in litigationgenerally, 'differentjurors may be persuaded by different pieces of evidence, even when they agree upon the bottom line. Plainly, there is no general requirement that the juryreach agreementon the preliminary factual issues which underlie the verdict." [FN151] Moreover, at least one federal court has held expresslyin a civil case that, while a verdict must be unatimous, jurors need not be unanimous in their reasoning. [FN152] Nor does the standard treatise on jury instructions in federal court indude an instruction requiring juror unanimity with respect to the jury's reasoning, [FN153] In an article written as an academic, Justice Ginsburg went even further, arguing that even when ajury is asked to return a special verdict, unanimity should be required only with respect to "uldimate issues." [FN154] Inshot, there is no teason to believe that a litigant may insist that jurors follow the same reasoning in reaching a verdict. [FN155]

It could be argued that this conclusion does not apply to bifurcated proceedings because the decisionmaking process is materially different in such cases. Whenjurors in an ordinaryproceeding are unable to agnee on the facts demonstratingnegligence, for example, they also may be unable to agree on related issues like the allocation of comparative negligence. In other words, material differences in jurors' understanding of the evidence may result in a hung jury. By contrast, material differences in the undetstanding of evidence by separate juries in bifurcated proceedings would not force the later jury to hang.

There is no reason to view this difference between ordinary and bifurcated proceedings as a distinction of constiturional imporr. As long as a reasonable jury may tely on different views of the evidence, there is nothing unfair about allowing a later jury to decide matters not formally resolved by the first jury. Because alater jury is as capable of evaluating the evidence presented to it as is the first jury, a later jury's evaluation of the evidence is as likely to be as accurate as the first jury's evaluation.

Moreover, provided the parties are permitted to litigate fully unresolved matters before the later jury, there is no reason to give special status to the undisclosed reasoning of the first jury. While the Reexamination Clause gives special status to the first jury in some circumstances, it does so only to effectuate the policies of the Clause. We treat the formal findings of the first jury as final, for example, to 
comply with a constitutional policy of limiting the review of verdicts. In the absence of a requirement that ajury be unanimous as to its reasoning, the Clause provides no basis for requiring that special status be given to the reasoning of the first jury. [FN156] Thus, the mere fact that the first jury happened to deliberate first is insufficient to support the conclusion that the firstjuy's reasoning is entitled to constitutional protection.

While the Reexamination Clause does not forbid a policy that would require the first jury to retum a special verdict disclosing in full the jury's reasoning process, such a requirement would be impractical. As I discuss below, the first jury in a bifurcated proceeding must provide sufficient guidance to allow later junies toimplement the firstjury's formal findings without confusion or uncertainty. [FN157] For example, when a plaintiff proposes altemative theories of negligence it may be necessary to ask the first jury to indicate the theory or theories on which it relied to find the defendant negligent. To require significandy more than this, however, is probablynot desirable because it would significantly increase the possibility that the first jury would be unable to reach a verdict and would make the task of later juries considerably more difficult. [FN158] For that reason, it is likely that later junies will often need to inquire into issues decided by an earlier jury. It is to this kind of inquiry that I turn now.

\section{Inquiries into Previously Decided Issues}

The Reexamination Clause generally forbids the retrial of issues that have been determined by a valid jury verdict. [FN159] In this part, I address a different issue: does the Reexamination Clause prohibita juryin the second phase of a bifurcated ptoceedingfrom rehearingevidence on an issue that has been decided by an earlier jury? This is an important question because, in the alssence of anexhaustively detailed special verdict, overlapping issues can be fairly tried in abifurcated proceeding only if a laterjury is allowed to inquire into issues decided by the first jury. [FN160] In a comparative negligence case, for example, a second jury would be unable to decide the comparative negligence issue without hearing evidence on the previously adjudicated negligence issue. [FN161] I do not mean to suggest that the first trial will have to be repeated in its entirety. If the special verdict forms are properly drafted, negligence theories rejected by the firstjury presumably would be excluded from the consideration of later juries. There is no question, however, that substantial repetition would be required.

There is no support for the view that inquiringintoan issue decided by anearlier jury violates the Reexamination Clause, especially if the purpose of the inquiry is not to confirm or reject the earlier finding. [FN162] If the Clause is understood to apply only to an impairment of the right to ajury trial, the mere fact that a later jury rehears the evidence presented on an issue cannot violate the Reexamination Clause. Readdynamically, however, the reference to "common law" in the Clause arguably is broadenough to permit the courts to fashion and enforce a fundamentalnom against the wasteful rehearing of evidence.

I have serious doubts that reading the reference to "conmon law" in this way would be appropiate. Because the Reexamination Clause was intended to limit the scope of the review of verdicts, it appears that the Clause's reference to "conmon law" at most was intended to pernit appropriate adjustments in the balance of power between local juries and the federal judiciary. While the Clause 
mandatescertain rules of directestoppel to avoidevasion of limits on the review of verdicts, [FN163] a rule prohibiting later juries from tehearing evidence on issues presented to the first jury would serve no such purpose. For that reason, an approach properly tethered to the purposes of the Founders would not conclude that simply inquiring into an issue decided by a previous jury is a violation of the Reexamination Clause. [FN164]

Even if the Reexamination Clause were read as a warrant for judicial lawmaking separate and apart from its purposes, there still would be no basis for conduding that an inquiry by a later jury into facts tried by an earlier jury would be prohibited under the Clause. It is not reexamination per se that is troublesome, but its consequences, which may include the loss of finality and the burdening of litigants or the courtsystem. [FN165]

Iaccept the proposition that atsome point the burdensimposedon a litigantmaybe so unreasonable as to implicate the Constitution. The Seventh Circut so recognized in Continental Can Co., U.S.A. v. Marshall, [FN166] in the course of holding that governmental harassment of a private party through lidgation violated the Due Process Clause: "(T) he Governmentcannot, without violating due process, needlessly require a party to undergo the burdens oflitigation. ... The Government is notaringmaster for whom individuals and corporations must jump through a hoop at their own expense each time it commands." [FN167] Because everygovernmental commandinevitably inqposes burden and expense on someone, however, the Constitution-including the Reexamination Clause--at mostcouldrequire only that litigation procedures not be so unreasonably burdensome in light of their objectives as to be fundamentally unfair. [FN168]

Courts have sometimes assumed that bifurcation of overlapping issues is wasteful. [FN169] But there is no basis for conduding that the burden inherent in requiring parties to presentevidence more than once raises an issue of constitutional dimension. Federal courts often use general verdicts, for example, even though ageneral verdict for the defense may resut in retrial of the same issue in a later case. [FN170] Similarly, federal courts have refused to grant preclusive effect to an alternative finding of fact not confirmed on appeal, [FN171] even though this rule may result in another trial of the same issue by another jury. Bifurcation in the face of overlapping issues similarly cannot be characterized as imposing a constitutionally unteasonable burden on litigants.

To begin with, if the court approves bifurcation in the face of crossover issues, the parties in essence trade the risk of repetition should the plaintiffs win the class trial for the end of litigation and significantlyreduced costs should the defendants win the class trial. The more likely a defendant is to win the class trial on common issues, the more likely that bifurcation will prove economical. [FN172] Even when plaintiffs win the class trial, the benefits of bifurcation may outweigh the costs. When, for example, the case pivots on the class issue, resolution of that issue may facilitate settlement of the entire litigation, resulting in significantly reduced costs of litigation. [FN173] Thus, even when overlapping issues are involved, bifurcation may save both the parties and the couts time and money if used in a discriminating fashion 
Bifurcation serves a second important purpose. Even when the amounts at stake are large enough to make it feasible for plaintiffs to bring individual suits, the defendant may enjoy a snategic advantage in resources that plaintiff's can overcome only through collective action. [FN174] Without certification of an issue class, collective action on the part of plaintiffs becomes significantly more difficult. [FN175] Because suits should be resolved on the merits rather than as a result of disparities in weal th, certification ofa Federal Rule 23(c) (4) (A) issue class may promote justice, even if certification may make the litigation as a whole more expensive should the defendant lose the class trial. [FN176]

The issue class promotes the integrity of the fact-finding process in yet another way. Under the principles of offensive collateral estoppel, a defendant who loses the first in a series of suits involving the "same issue" may be bound by adverse finding on that issue in later suits. [FN177] This rule may lead to anomalous results when the furst suit is atypical in a way that may affect thejury's verdict. For example, an unusually sympathetic plaintiffin the first suit tried to judgment may skew ajury's decision on common issues in a way that may benefit all future plaintiffs to the detriment of the defendant. [FN178] Whether or notone sees a legitimate role for jury sympathy in the trial of a case, there can be nojustification for giving these sympathies effect beyond the specific case ajury hears. The use of an issue class to resolve common issues may avoid giving the case of an unusually sympathetic plaintiff undue weight in the resolution of a mass tort and makes it more likely that jury decisions on common issues will not be affected by irrelevant factors. [FN179] While defendants typically prefer to assume the risk of collateral estoppel rather than face collective action by plaintiffs, [FN180] the procedural systemhas a separate and distinctinterestin theintegrity of its fact-finding process.

In short, bifurcation in the face of crossover issues may serve a reasonable purpose, even if certification of an issue class creates a tisk that the litigation as a whole will be more expensive than it would be otherwise. Because the Constitution has never been interpreted to forbid the imposition of cost and inconvenience on parties when there is a reasonable basis for doing so, the Fifth and Seventh Circuits' interpretation of the Reexamination Clause cannot properly be based on the cost or inconvenience that results from the rehearing of evidence on an issue that has been decided by an eartier juty.

\section{The Atgument from Precedent}

\section{The Misreading of Gasoline Products}

Ihave sought to demonstrate that the Fifth and Seventh Circuits' analyses do not accord with first principles. The Fifth and SeventhCircuits, however, make little effort to defend their conclusions on first principles. Rather, the decisions rely heavily on the assettion that Gasoline Products holds that the separate trial of overlapping issues violates the Seventh Amendment. [FN181] I tum therefore to an analysis of Gasoline Products and condude that the Fifth and Seventh Circuits' reliance on that decision is misplaced. Gasoline Products did not decide that ovetlappingissues could notbe tredseparately, as the Fifthand Seventh Circuits assume in Rhone-Poulenc and Castano. [FN182] 
In Gasoline Products, the First Circuit set aside in part the verdict on a contract counterclaim because the trial court had mischarged the jury on damages. The counterclaim defendant, Gasoline Products Company, soughtreview by the Court, arguing that limiting a new trial to danages alone would violate its right to ajury trial. The Cout rejected the argument that a verdict cannot be set aside in part, holding expressly that the Seventh Amendment does not always require a unitary trial of a claim. [FN183] The Court nonetheless refused to permit a retrial limited to damages because damages were not "separable" from other issues, meaning that the issues could not be tried separately without "injustice." [FN184] As the Courtput it, "the question of damages on the counterclaim (was) so interwoven with that of liability that the former (could not) be submitted to the jury independently of the latter without confusion and uncertainty, which would amount to a denial of a fair trial." [EN185] Thus, the Coutt ordered a new trial as to all the issues.

One might be incline to think thatoverlapping issues by definition are notseparable. [FN186] However, as even the Fifth Circuit has recognized outside the highly charged class action context, that is not what Gasoline Products stands for [FN187] A close reading of Gasoline Products confirms that the Court did not define "separable" to mean "without overlap." Issues are separable, that is not "interwoven," if they can be tried separately without "confusion and uncertainty." [FN 188] As the Second Circuit has stated, the Count's "concern (in Gasoline Products) was with the ability of the second jury to function under the limitationsimposed by the (First Circuit)." [FN189] Thus, the proper focus is on the jury'sability to decide the case fairly. From this perspective, the Court's invocation of the Seventh Amendment can be viewed as a specialized application of a general due process concem for the accuracy of the decisionmaking process. [FN190] In other words, the Seventh Amendment's Trial-by-Jury Clause requires that a jury not be denied information needed to reach a just verdict.

It could be argued that the separate rial of over lapping issues inevitably results in confusion and uncertainty. The risk of confusion and uncertainty can be avoided, however, when later juries are provided with the information they need to understand and apply the findings of the firstjury. [FN191] In a comparative negligence case, this may mean that evidence on the theories of negigence adopted by the firstjury may have to be presented a second time. Circuit courts have permitted retrials limited to conparative negligence insuchcircunstances. [FN192] In Akermanis v. Sea-Land Service, Inc., [FN193] for example, the Second Citcuitheld that the districtcoutcould limitretrial to the question of comparative negligence, on the condition that the parties would be allowed to intoduce the evidence of negligence on retrial for purposes of allocating fault between the parties. [FN194]

Assuch cases illustrate, the legal standard enunciatedin Gasoline Products provides no support for the view that the case forbids the separate trial of overlapping issues in all cases. It could be argued, however, that Gasoline Products is prenised on the background assumption that the reasoning behind a valid verdict controls later litigation. [FN195] Because exhaustively detailed special verdicts would make the separate trial of overlapping issues impractical, [FN196] this assumprion, if givencredence, would have virtually the same effect as interpreting Gasoline Products to forbid the separate trial of overlappingissues in all cases. [FN197] 
The argument that the Courtrelied on this assumptionmight be based on the Court'sconclusion that there would be a risk of confusion and uncertainty in a partial retrial because the second juy would not have been authorized to decide a number of open issues:

The verdicton the counterclaim may be taken to have established the existence of a contract and its breach. Nevertheless, upon the new trial, the jury cannot fix the amount of damages unless also advised of the terms of the contract; and the dates of formation and breach may be material, since it will be open to petitioner to insist upon the duty of tespondent to minimize damages.

[FN198]

... But the present verdict ... cannot be taken as establishing any of these material facts.

While ambiguous, the quotation does not provide much support for an argument that the Court assumed that the undisclosed reasoning of a jury is binding. If the Court had done so, there is every reason to believe that the Court would have articulated the assumption in the form of arule. After all, astatement that the reasoning behind a jury verdict is binding would have provided at least as illuminating an explanation of the Court's decision to vacate the verdict in its entirety as the Court's "confusion and uncertainty" standard. Further, it seems unlikely that the Court would have relied sub silentio on an assumption that was far from settled. Indeed, the conclusion that the jurors must be unanimous in their reasoning had been frequently questioned in the state courts but had never been addressed by the Supreme Court. [FN199]

It is far more plausible to conclude that the Court assumed that the matters identified in the above quotation were outside the scope of the First Circuit's retrial order. In essence, the Court appears to have narrowly construed the order as permitting a retrial only of matters infected by the enroneous instructions. [FN200] While this seems like an amazingly narrowinterpretation of the Fist Circuit'sorder, this is exactly how a similar order appears to have been construed in Norfolk Southem Railroad Co.v. Ferebee, [FN201] a case on which Gasoline Products relied. [FN202]

For these reasons, it seems implausible that the Courtassumed that the undisclosedreasoning of ajury is entitled todeference. Putting aside this implausible assumption, there appears to be no basis for concluding that Gasoline Products for bids the separate trial of overlapping issues in all cases. Thus, RhonePoulenc and Castano find no support in Supreme Courtprecedent for aper se ban on the separate trial of overtappingissues.

\section{The Relevance of Gasoline Products}

Ihave argued above that neicher the standardenunciated by Gasoline Products nor the Court's background assumptions forbid the separate trial of overlapping issues. But that does not mean that Gasoline Products is irrelevant. Even if the Courthad read the First Circuil's order more generously, for example, acomplete retrial of the case would have beenrequired under the circumstances. In view of the disagreement between the parties as to the very terms of the contract, the general verdict retumed by the 
first jury could not provide the second jury with adequate guidance. In a complex case like Gasoline Products, a verdict that simply states that the defendant breached the contract cannot assist a later jury in deciding, for example, how the contract has been breached. This would pose a serious problem if the second jury were unable to conceptualize a breach. [FN203] If the jury nonetheless sought to obey its instructions despite its inability to see a breach, the resulting "confusion and uncertainty" could easily lead to an arbitrary verdict, [FN204] precisely the outcome the Gasoline Products Court was determined to avoid.

In oher words, Gasoline Products'sconfusion and uncertainty standard requires that separate trials of overlapping issues be properly structured. The opportunity to structure the case to address the needs of a later jury was not available in Gasoline Products because neither the parties nor the trial court foresaw that a later jury would need guidance from the first. A well thought-out bifurcatedproceeding, by contrast, should be able to avoid the sort of problem that would have made a limited retrial in Gasoline Products unfair: Put another way, if the special verdict form is drafted properly to neveal the basis of the first jury's findings and essential evidence is re-presented to later juties, the mere fact of overlap should not prevent later juries from deciding the case in a fair manner. [FN205]

In Rhone-Poulenc, for example, alaterjuy could have been instructedon the basis of a properly drafted special verdict that defendan's's fal ure to guard against the contamination of its blood products by Hepatitis Bshould be deemed negligent. Because such an insturuction can be easily grasped and applied, there might have been no need to ask more detaled questions of the first jury on the question of negligence. Ofcourse, if a party had believed that greater specificity on the negligence question in the first phase of the bifurcated proceeding would avoid "confusion and uncertainty" in the second phase, that party could have argued for a more detailed special verdict form. In the second phase of the proceedings, juries could have been advised of the first jury's findings and could have been permitted to rehear evidence on defendant's negligence for the purpose of comparing defendant's negligence against any negligence by the plaintiff, Stuctured in this way, there is no reason to believe that later juries would have faced a risk of "confusion or uncertainty" the only relevant concern expressed by Gasoline Products. [FN206]

\section{IV.Conclusion}

Ihave sought to show that the separate trial of overlapping issues does not necessarily violate the Seventh Amendment Reexamination Clause. The Clause requires only that later juries respect the formal findings of the first jury. Within these broad parameters, the Clause does not prohibitlater juries from independently evaluating evidence on a pteviously decided issue in order to decide a related issue. For that reason, the Clause allows a jury charged with deciding the issue of comparative negligence to rehear evidence presented to an earlier jury on the defendan's negligence, provided the later jury understands that the formal findings of the earlier jury are binding. 
Gasoline Products imposes an additional requirement under the Trial-by-Jury Clause. The formal findings of the firstjury must be in a form that a later jury can easily grasp and apply. It is notenough, for example, for the firstjury toreturn a verdict of negligence. Iflater juries are to apply the first jury's verdict without perplexity, the verdict must be specific enough to explain, at least in a broad outline, how the defendant was negligent. Otherwise, the parties face an unacceptable risk that a later jury will le unable to render a reasoned verdict. Provided the needs oflater juties are considered when the court and praties draft the first verdict, however, later juries should be able to render an appropriate verdict.

In short, the mechanical approach championed by the Fifth and Seventh Circuits cannot withstand sctutiny. The separate trial of overlapping issues may not always be desirable. But there is no sound basis forconcluding that the convocation of a second jury in such circumstances will necessarily lead to violation of the Seventh Amendment. Reliance on the Seventh Amendment Reexamination Clause thus obscures the real issue: Will certification of an issue class assist in the fair and accurate determination of a particular controversy?

[FN1]. U.S. Const amend VI, cl. 2. The Seventh Amendment, of course, also protects the right to a jury trial. U.S. Const. amend. VI, cl. I "In Suits atcommon law, where the vatue in controversy shall exceed twenty dollars, the right of trial by jury shall be preserved....").

[FN2]. In re Rhone-Poulenc Rore, Inc., 51 F3d1293 (7th Cir 1995).

[FN3]. I use the term "bifurcation" in this Article torefer to separate trials by different juries of one or more issues relevant to a single claim.

[FN4]. An issue class is a class certified to adjudicate specific issues rather than entire claims. See Fed, R. Civ. P.23 (c) (4) (A) ("When appropriate... an action may be brought or maintained as a class action with respect to particular issues."); Manual for ComplexLitigation $\$ 30.17$ (3d ed. 1995). The certification of an issue class typically means that the litigation will be tried in at least two phases; that is, after the class issues are tried, the remaining issues in the litigation will be addressed by different juries in individualfollow-onsuits.

[FN5]. Judge Posner also concluded that the negligence and proximate cause issues overlapped. Infranote 98.

[PN6]. See, e.g, Castano v. Americin TobaccoCo,84F3d 734 (5th Cur 1996) (holding that the risk of a second jury reevaluating the defendant tobaccocompany's fault was too great); Rhone-Poulenc, 51 F3d at 1293; Arch v. American Tobacco Co., Inc, 175 FR.D. 469 (E.D. Pa. 1997) (following the reasoning in Castano that bifurcation of issues would violate the Seventh Amendment); Smithv. Brown \&Williamson Tobacco Corp, 174 ERD.90,96 (W.D.Mo. 1997) (deciding thatusingseparate juriesmight violate the Seventh Amendment becatsse issues are too "intertwined"). The argument is equally applicable to any form of bifurcation that involves the separate trial by different juries of two or more issues relevant toaclaim. See, e.g, Inre Dow ConningCorp., 211BR.545, 588 (Bankt: ED. Mich. 1997) (considering the 
reexamination problemoutside the issue class context). Federal Rule of Civil Procedure 42 (b) permits such bifurcation, without regard to certification of an issue class:

The court, in funtherance of convenience or to avoid prejudice, or when separate trials will be conducive to expedition and economy, may order a separate trial of any number of clams... or issues, always preserving inviolate the right of trial by jury as declared by the Seventh Amendment to the Constitution....

Fed R.Civ.P.42(b).

[FN7]. See Inre Telectronics PacingSys., Inc., 168 ERD. 203,210 (S.D. Ohio 1996) (questioning Judge Posner's faith in the jury system); In re Copley Pharm., Inc., 161 FR.D. 456, 460 (D. Wyo. 1995) ("This) Court declines Copley'sinvitation to follow the Seventh Circuit's application of economic justice to the Federal Rules ofCivil Procedure."); GeoffreyC. Hazardetal., Pleading and Procedure: State and Federal Cases and Materials 60,73 (7thed. Supp. 1997) (criticizingJudge Posner's use of mandamus and citing Michael Orey, Posner's Bearish Dissent, The Am. Law, May 1995, at 73); Heather M. Johnson, Note, Resolution ofMass Product Liability Litigation Within the Federal Rules: A Case for the Increased Use of Rule 23(b) (3) Class Actions, 64 Fordham L. Rev. 2329, 2373-79 (1996) (arguing in favor of class certification); RecentCase, Class Actions-Class Certification of Mass Torts-Seventh Curcuit Overturns Rule 23(b) (3) Certification of a PlaindiffClass of Hemophiliacs-Inre Rhone-Poulenc Rorer, Inc., $51 \mathrm{~F} 3 \mathrm{~d}$ 1293 (7th Cir), cert. denied 116S. C. 184 (1995), 109 Harv. L. Rev. 870,871-74 (1996) (criticizing decertification of the class, the inquiry into merits, and the use of mandamus); see also 18 Class Action Rep. 161, 178-79, 181-82 (1995) (criticizing the use of mandamus and discussion of negligence law); 18 Class Action Rep. 670,695-97 (1995) (criticizing Rhone-Poulenc as the" worst" classcertification decision).

[FN8]. Professor ]ohn Coffee is a notable exception to the relative silence that has greeted this portion of Judge Posner'sopinion, but Professor Coffee does not purport to analyze in any depth Judge Posner's holding in this respect. See John C. Coffee, Jr, Class Wars: The Dilemma of the Mass TortClass Action, 95 Colum. L. Rev. 1343, 1440 (1995) (stating that "(t)his Seventh Arnendment objecrion seems a weak argument" and suggesting that, if a limited class were certified after a finding that plaintiffs had a probability of sticcess, "itseems doubfful thateven the Seventh Circuit would finda Seventh Amendment violation"); see also Valentino v. Carter-Wallace, Inc., 97 F3d 1227, 1232 (9th Cir 1996) ("This (Seventh Amendment) concern of the Rhone-Poulenc coturtmay not be fully in line with the law of this circuit. ...").

[FN9]. See infra note 93 (describingsuch Fifth Circuit decisions).

[FN10].Manual for Complex Litigation, supranote 4, \$30.17 n.704 (ciring Alabama v Blue Bird Body Co., 573 F2d 309 (5th Cir: 1978), the seminal FifthCircuit decision); see infra note 92 (collecting citations).

[FN11].Some courts have permitted individual issues to be resolved through statistical sampling techniques. E.g., Hilao v. Estate of Marcos, $103 \mathrm{~F} 3 \mathrm{~d} 767$ (9th Cir 1996). While individual issues in mass tort dispute cases can be resolved by sampling, use of this method is highly controversial. See, e.g., In re 
ChevronU.S.A., Inc., 109 F3d 1016, 1022 (5th Cir 1997) (Jones, J., specially concuning) ("Thave serious doubts about the procedure even where, as here, (the defendant) agreed to use of a statistically sound bellwether tral process."); Hilao, 103 F.3dat 787,788 (Rymer,], concurring and dissenting in part) (stating that the use of statistical sampling to resolve individual damage claims "leaves me 'with a profound disquie" ") (quoting In re Fibreboard, 893 F2 d 706,710 (5th Cir 1990)). Indeed, the Fifth Circuitrecently rejected the use of statisucical sampling rechniques in amass tort case. Ciminov. Raymark Indus, Inc, Nos. 93 4452 through 93-4611,1998 WL 48017 (5 h Cir Aug. 17, 1998) (rejectinguse of the technique in a mass tortcase). For academic discussion of statistical sampling techniques in the mass tortcontext, see, for example, Robert G. Bone, Statistical Adjudication: Rights, Justice, and Utility in a World of Process Scarcity, 46 Vand. L. Rev. 561 (1993); Michael J. Saks \& Peter David Blanck, Justice Improved: The Unrecognized Benefits of Aggregation and Sampling in the Trial of Mass Torts, 44 Stan. L. Rev. 815 (1992).

[FN12]. Samuel Issacharoff, Class Action Conflicts, 30U.C. Davis L. Rev 805, 832 (1997).

[FN13]. Itmay be possible toresolve some mass torts without adjudication by certifying a dass for purposes of settlement. In Amchem Prods, Inc. v. Windsor, 117 S. Ct. 2231 (1997), the Courtaddressed the appropriateness of settlement classes for the first time. The impact that Windsor will have on the certification of such classes is unclear: Whatever the fate of the settlement class, however, the availability of the issue class temains important. The possibility that a suit will be tried is essential to insuring a fair settlement: See Issacharoff, supra note 12, at 812 ("The lawyer who has entered intonegotiations on the basis of asettlement class that could never have been tried is in a weak position to hold out.").

[FN14]. E.g., Arthur Young \& Co.v. U.S. Dist. Cout, 549 F.2d686 (9th Cir, 1977) (affirming bifurcation plan after applying Gasoline Products's confusion and uncertainty standard); ct. Gasoline Prods. Co. v.Champlin Ref.Co., 283 U.S.494, 501 (1931) (holding that apartial new trial is pernissible when it would not lead to confusion and uncertainty).

[FN15].84F3d734 (5thCir. 1996).

[FN16], I follow Professor Charles Wolfram, among others, in my use of terms "static" and "dynamic" torefer to possible interpretations of the reference to "commonlaw" in the Seventh Amendment SeeCharles W.Wolfram, The Consticutional History of the Seventh Amendment, 57 Minn. L. Rev.639, 744-45 (1973); see also Jack Friedenthal etal, Civil Procedure 489 (2ded. 1993) ("(I) tis now clear that proper Seventh Amendment analysis requires application of a dynamic concept....").

[FN17]. See, e.g., Gasperini v. Center for Humanities, 5 18 U.S. 415, 451-52 (1996) (Scalia,], dissenting) ("The content of that law was faniliar and fixed."); Baltimore \& Carolina Line, Inc. v. Redman, 295U.S. 654,657 (1935) ("The right to trial byjury thus preserved is the right which existed under the English common law when the Amendment was adopted."); Dimick v. Schiedt, 293U.S. 474, 476 (1935) ("Inotder toascertain the scopeand meaning of the Seventh Amendment, resortmust be had to the appropriate rules of the common lawestablished at the time of the adoption of that constirutional 
provisionin 1791.") (ciung Thompson v.Utah, 170 U.S.343, 350 (1898); Patton v.United States, 281U.S. $276,288(1930))$.

[FN18].See Redman, 295 U.S. at657 (1935) (stating that the aim of the Seventh Amendment "is to preserve the substance of the commmon-lawight to tuial byjury, as distinguished frommere matters of formor procedure"); Walker v. New Mexico \&S. Pac. RR, 165 US. 593,596 (1897) (holding that the Seventh Amendment's "aim is not to preserve mere matters of form and procedture but substance of tight").

[FN19]. See Dimick, 293 U.S. at 490 (Stone, J, dissenting) ("There is nothing in (the Seventh. Amendment's) history or language to suggest that the Amendment had anypurpose but to preserve the essentials of the jury trial as it was known to the common law before the adoption of the Constitution."); Douglas Laycock, Due Process and Separation of Powers: The Effort to Make the Due Process Clause Nonjusticiable, 60 Tex. L. Rev. 875,894 (1982) ("Tóncorporate a frozen conmon law is to incorporatea contradiction in terms."); Wolfram, supranote 16, at 736 (arguing that by 1791 "acommonly understood concept of 'common law' had become that of a process characterized by occasional flexibility and capacity for growth in order to respond to changing social pressures rather than that of a fixed and immutable body of unchanging rules"); see also infra note 34 and accompanying text (quoting footnote in which the Gasperini Count rejected astatic interpretation of the Reexamination Clause).

[FN20]. See infra note 118 and accompanyingtext (notingthat bifuncation was virtually unknown atcommonlaw).

\section{[FN21]. Dimick, 293US. at474.}

[FN22]. Additur permits a court tocondition a new rial on defendant's falure toconsent to an increase in damages when plaintiff complains that the jury's damages award is inadequate. See Fleming James, Jretal., Civil Procedure 400-01 (4thed. 1992).

[FN23]. Dimick, 293 U.Sat 476 ("In order to ascertain the scope and meaning of the Seventh Amendment, resort must be had to the appropiate rules of the common law established at the time of the adoption of thatconstitutional provision in 1791.") (citing Thompson v. Utah, 170 U.S. 343,350 (1898); Pattonv.United States, 281 U.S. 276, $288(1930)$ ).

[FN24]. Id.at487.

[FN25]. See, e.g, Parklane Hosiery Co. v. Shore, 439 U.S. 322, 337 (1979) (quoting Galloway v. United States, 319 U.S. 372 (1943)); Galloway, 319 U.S. at 392 ("The more logical conclusion . . is that the Amendment was designed to preserve the basic institution of jury trial in only its most fundamental elements...."); see also Colgrove v. Battin, 413 U.S. 149 (1973) (rejecting the argument that a civiljury of six would be unable to properly perfon the functions of a jury). See generally Roger W. Kirst, Judicial Controlof Punitive Damage Verdicts: A Seventh Amendment Perspective, 48 SMUL. Rev.63 (1994) (discussing the Supreme Court's evolving interpretation of the Seventh Amendment). 
[FN26]. See Galloway, 319U.S.at388-96 (approving directed verdict); Fidelity \& Deposit Co. of Md.v. United States, 187 U.S.315 (1902) (approvingsummary judgment).

[FN27]. As Justice Black noted with respect to directed verdict motions:

This new device contained potentialities for judicial control of the jury which had not existed in the demurter to the vidence... (D)ernurting to the evidence was risky business; for in doing so the party notonlyadmitted the truth of all the testimony againsthim but also all reasonable inferences whichmight be drawn from it... Imposition of this risk was no mere technicality; for by making withdrawal of acase from the jury dangerous to the moving litigant'scause, the early law went far to assure that facts would never be examined except by ajury.

Galloway, 319 U.S. at 402-03 (Black, ], dissenting); see also Parklane, 439US. at 346 (Rehnquist, J., dissenting) ("(T) sanction creation of procedural devices which limit the province of the jury to a greater degree than permitted at common law in 1791 is in direct contravention of the Seventh Amendment.").

[FN28].518U.S.415(1996).

[FN29].413U.S. 149 (1973).

[FN30]. Id, at 156 (quoting Williamsv. Florida, 399 U.S. 78, 99 (1970)).

[FN31]. Id. at 152 n.6 ("The reference to 'common law' contained in the second clause of the Seventh Amendment is inelevant toour present inquiry because it deals exclusively with the prohibition contained in that clause against the indirect impaiment of the right of trial by jury through judicial reexamination of fact findings of a jury oher than as permitted in 1791."). Similarly, in Parklane HosieryCo. v. Shore, the Court stated that Dimick was irrelevant because the issue in Parklane did not involve reexamination of facts decided by a jury. See Parklane, 439 U.S. at $336 \& n .23$ (arguing that Dimick's staticapproach was notcontollingbecause Dinick involved the Reexamination Clause). Justice Rehnquist protested indissent that Dimick was in fact relevant. See id, at 345 n.12 (Rehnquist,], dissenting) ("There is no intimation in (Dimick) that the firstclause should be treated any differently from the second.").

[FN32]. The Court held that the Reexamination Clause does not prohibit an appellate court from reversing a denial of a new trial motion based on the award of excessive damages, provided the trial court abused its discretion in denying the motion. Gasperini, 518 U.S. at 436 (holding that "(n)othing in the Seventh Amendment... precludes appellate review of the trial judge's denial of a motion to set aside (ajury verdict) as excessive") (citing Gunenthal v. Long Island R.R Co., 393 U.S. 156, 164 (1968)).

[FN33]. See Gasperini, 518 U.S. at 433 n.16 (noting that Justice Stone's dissent "invit(ed) rethinking of the additur question on a later day").

[FN34].Id at436n.20. 
[FN35].See id. at461 (Scalia, ], dissenting) ("T) here is of course no comparison between the specificity of the command of the Reexamination Clause and the specificity of the command that there bea "jury."'); see also Richard H. Fieldetal, Civil Procedure 738 n.c (6thed. 1990) (noting thatonemight "read the Seventh Amendment's language to permit pursuit of policy in much of jury practice, but nevertheless impose astricter historical test under itsre-examination clause").

[FN36].Compare Gasperini, 518 US. at 443-44 (Stevens, J, dissenting) (arguing that the Court at Westminster that granted new trials at common law was an appellate tribunal), with id. at 455.57 (Scalia, J, dissenting) (arguing the contrary). This issue has long been the subject of debate. See, e.g, 11 Charles Alan Whight \& Arthur Miller, Federal Practice and Procedure \$ 2819 (2ded. 1995) (outlining the evolution of the debate); William Blume, Review of Facts in Jury Cases-TheSeventh Amendment, 20j. Am. Jud. Soc. 130 (1936) (arguing that appellate review of grantor denial of new trial motion is not prohibited by the Seventh Amendment); Willian Riddell, New Trial at the Common Law, 26 Yale L.]. 49 (1916) (arguing that under English conmon law a new trial could not be granted by the trial judge, but only by the "Courtabove").

[FN37]. See Gasperini, 518U.S. at 432-33 ("In keeping with the historic understanding, the teexamination clause does not inhilit the authority of trial judges to grant new trials "for any of the reasons for which new trials have heretofore been granted in actions at law in the courts of the United States.") (quoting Fed. R. Civ. P.59(a)) (emphasis added).

[FN38]. Id. at 435; cf. RichardH. Fallonetal., Hart \& Wechsler's The Federal Counts and The Federal System 602 (1996) (noting that "in practice, the Seventh Amendment has not proven to be an important limit on Supreme Court review"); Paul Carnington, The Seventh Amendment: Some Bicentennial Reflections, 1990 U. Chi. Legal F.33, 46 ("Even a federal civil jury may not deny due process of law by rendering a verdict unsupported by evidence.").

[FN39]. Gasperini, 518U.S. at451-52 (Scalia, ], dissenting).

[FN40]. Id. at461.

[FN41].U.S. Const. art. III, $\$ 2, \mathrm{cl} .2$.

[FN42]. Wilfred]. Ritz, Rewriting The Judiciary Act of 1789, at67 (1990); see also id. at 7 (noting that "appeal" was used in equity).

[FN43]. See United States v. Wonson, 28 F.Cas. 745, 748 (C.C.D. Mass. 1812) (No. 16,750) (noting possibility of retrial byjuryon appeal in Massachusetts, New Hampshite, and Rhode Island); Julius Goebel, Jr, History of the Supreme Court of the United States: Antecedents and Beginnings to 1801, at 28-29 (1971) (noting that in New England colonies a second trial by jury could be had on appeal); The Federalist No. 83, at 547 (Alexander Hanilton) (E. Earle ed., 1941) (stating that in Rhode Island, Connecticut, Massachusetts and New Hampshire, "( $(t)$ here is an appeal of course from one jury to 
another...."); Ritz, supranote 42, at 42 ("In .. Massachusetts, New Hampshire, and Rhode Island ... (t)he decision ... resulting from a trial in an inferior tribunal could be appealed to a superior tribunal where a second and entirely new trial could be had."). Hamilton also claimed that in Georgia a party was entitled to aretrial byjury on appeal. The Federalisst No. 83, at 546 ("In Georgia ... an appeal of course lies from the verdict of one jury to another."); cf. Goebel, supra, at 35 (citing Georgia statute that "stipulated an appeal to the General Court which was empowered to examine process and wimesses' depositions or to order a new trial before itself").

[FN44]. See Wythe Holt, "To Establish Justice": Politics, The Judiciary Act of 1789, and the Invention of the Federal Courts, 1989 Duke L.J. 1421, 1465-66 (noting amendments made in the Constitutional Convention to clarify the powers of the Supreme Court). According to Professor Holt:

The members of the Convention wanted toensure... that courtssitting without juries, particularly the Supreme Courthearing appeals in the manner of the civil law, would be permitted. It is clear that they hoped that the Supreme Courtwould be able to overturn (torepeat Madison'srevealing words) "mproper Verdicts in State tribunals obtained under the biassed directions of a dependent Judge, or the local prejudices of an undirected jury."

Id.

[FN45]. See, e.g., JackN. Rakove, Otiginal Meanings 319 (1996) (noting the potency of AntiFederalist claims about the insecurity of trial by jury); Wolfram, supra note 16, at 669 " "(T) he ratification process brought to lightsurongly felt popular beliefs about governmentand its relationship to the person in the street and the importance of the civil jury in preserving that relationship.").

[FN46]. See Rakove, supra note 45, at 319-21 (discussing concerns raisedby Anti-Federalists).

[FN47]. Seeid. at 321 (noting that in the most severe analyses, the Supreme Court's appellate authority "amounted to an effort to replace the common-law birthright of Americans with the dreadcivil law of Continental Europe"); see also The FederalistNo.81, at 530 (Alexander Hamilton) (E. Farle ed, 1941) (arguing that grant to the Supreme Court of appellate juriscliction both as to law and fact does not abolish trial byjury); The Federalist No. 83, supranote 43, at 538 (refuting argument that rial byjury was abolished by the fact that the Constitution guaranteed urial by jury only in criminal cases).

[FN48]. The Federalist No. 81, supranote 47, at $531-33$.

[FN49].SeeRakove, supranote 45, at 322 ("When Federalists insisted that Congress had wo be crusted to fashion arrangements for civil juries, they only encouraged their adversaries to regard it as the institution against which rights hadmost to be protected.").

[FN50]. See id. at 151 ("Anti-Federalists exptessed ... animus (toward the corrupting and expansive properties of power) most strongly when they examined those provisions of the Constitution that lay closest to the subjects on which generations of Anglo-American whigs had declaimed: the vital role of the jury in protecting local and customary rights against arbitrary acts of central power ....") 
(emphasis added); Wolfram, supra note 16, at 705-08 (noting that Anti-Federalists viewed the ability of juries to fiustrate unwise legislative and administrative policies as a justification for the jury).

[FN51]. See Holt, supranote 44, at 1468 ("(T) he oppression of debtors... and of poor people in general was also a constant theme of opposition to the proposed judiciary.); Wolfram, supranote 16, at 679 ("A state-by-state examination of the surviving records of the debates in the state ratification process reveals that ... concern for local debtors faced with the threat of suit in a federal court, without a jury, was one of the chiefmotivations for opposition to the Constiation.").

[FN52]. Wolfram, stupranote 16, at678.

[FN53]. As Professor Holt described the problem:

Apoor man who obtained judgment upon ajuryverdict in a federal trial courtor even in the state courts could be forced to retry the case in the Supreme Court, passibly at a distance of 500 miles, ..., and "he must bing his witnesses where he is not known, where a new evidence may be brought against him, of which he never heard before...."

Hol, supranote 44, at 1469; see Ritz, supranote 42, at 6 ("At the very least (renials in the national capital) would prove burdensome; at the worst, it would enable the rich litigant to abuse the poor litigant."); see also Wolfram, supra note 16, at 679-87 (collecringcitations to the ratification debates).

[FN54]. See Edith Henderson, The Background of the Seventh Amendment, 80 Harv. L. Rev. 289, 291 (1966) ("We have almost no direct evidence concerning the intention of the framers of the seventh amendment itself."); see also Wolfram, supra note 16, at 726.30 ("The skeletal nature of the record that has been uncovered hardly affords reassurance in its interpretation."').

[FN55].U.S.Const, amend. VII.

[FN56]. The writ of error historically had been used to review the judgments of common-law courts. Seegenerally Goebel, supra note 43, at 19-25 (comparing the appellate devices in English and American courts); Erwin C. Surrency, History Of The Federal Courts 201.03 (1987) (charting the historical development of appellate review). The writ of error did not permit retrials de novo on appeal and indeed was mote restrictive than modem appellate mechanisms. Id.

[FN57].28FCas. 745 (C.C.D.Mass. 1812) (No. 16,750).

[FN58]. See Gasperini v.Center for Humanities, 518U.S.415,451-52 (1996) (Scalia,], dissenning) ("The content of (the rules of the common law) was familiar and fixed.").

[FN59].See Dimick v.Schiedt, 293U.S.474,476 (1935) ("In order to ascertain the scope and meaning of the Seventh Amendment, resort must be had to the appropriate rules of the common law establishedat the time of the adoption of that constitutional provision in 1791.") (citing Thompsonv. Utah, 170U.S.343, 350 (1898); Pattonv. UnitedStates, 281 U.S. 276, 288 (1930)). 
[FN60]. See supranotes 25-27 and accompanyingtext (explaininghow the static interpretation has been discarded and why there is no principled way to return to it).

[FN61]. The Supreme Coutfell into a similar enor in Markman v. Westview Instruments, Inc., 517U.S.370,376 (1996) (quotingBaltimore \& Carolina Line, Inc. v. Redman, 295 U.S.654,657 (1935)), where the Countcited Wonson for the proposition that "since Justice Story's day, United States w. Wonson ..., we have understood that' $(t)$ he right of uial byjury thus preserved is the right whichexisted under the English common law when the Amendment was adopted." One reads Wonson in vain for confirmation that Justice Story believed the references to the common law in the Seventh Amendment mandated application of the English common law of 1791. See Wolfram, supra note 16, at 734 ("Justice Story did not purport to read the (Seventh) amendmentstatically").

[FN62]. In Wonson, the U.S. Attomey for the District of Massachusetts sought a rerial after removingasuit fromstate court. Justice Story, sitting as a Circuity Justice in the Circuit Court for the District of Massachusetts, decided that the Reexamination Cause prohibited a retrial of a suitremoved from state court Because Massachusetts procedurepernittedtetrial, Justice Story'sinterpretation of the Reexamination Clause tumed on whether it incorporated the law of the state in which the federal court sat or the common law of England. Justice Story concluded that the conmon law referred to in the Reexamination Clause was the common law of England. Wonson, 28 F.Cas. at 750 ("Beyond all question, the common lawhere alluded to is not the common law of any individual state, (for it probably differsinall), but it is the common law of England, the grand reservoir of all our jurisptudence.").

Justice Story's position was later endorsed by he Supreme Court in Capital Traction Co. v. Hof, 174 U.S. 1 (1899) (holding that the Seventh Amendment incorporates English common law and prohibits the retrial of facts previously tried by ajury); see also The Justices v. Muray, 76 U.S. (9 Wall.) 274 (1869) (holding that the Seventh Amendment's prohibition on the retrial of facts applies to cases tried by jury in state court and transferred or reviewed in federal court). Some modem commentators have suggested that) Justice Story was wrong. See, e.g, Wolfam, supranote 16, at 721 ("The historical materials furnish very little justification for ... reference to the English common law."). Professor Wolfram, for example, has argued that as an historical matter the Seventh Amendment was intended to incorporate state law. Id. at 732 n.275 ("The reference to 'common law' in the text of the seventh amendment... would beread to refer in an undifferentiated and general way to the 'law' of the state in which the federal courtsat."); id at 732-34 (arguing that state law inconporation is "the theory bestsupported by the historical materials"); see also Akhil Amar; Forward: Lord Canden Meers Federalism-Using State Constitutions to Counter Federal Abuses, 27 Rutgers L.J. 845, 852 (1996) (arguing that "the Seventh Amendmentmight be a kind of Erie-rule for the procedural issue of ury tral, requiring federal couts, ata minimum, to follow state jury rules"). I assume in this Article that the courts will adhere to the settled understanding that "common law" as used in the Reexamination Clause does not refer to state common law.

[FN63]. Wonson, 28ECas. at 750.

[FN64]. See infranores 66-70 and accompanying text (arguing that the Founders understood that the applicability of common law principles varied with local conditions). 
[FN65]. Morton]. Horwitz, The Transformation of American Law 1780-1860, at4-5,8 (1977) ("The equation of common law with a fixed, customary standardmeant that judges conceived of theit role as merely that of discovering and applying preexisting legal nules."); cf. William E. Nelson, The Americanization of the Common Law 19 (1975) ("Americans of the pre-Revolutionaryperiodexpected their judges to be automatons who mechanically applied immutable rules of law to the facts of each case.").

[FN66]. See Horwitz, stpranote65, at 5 ("Americans always insisted on the right to receive only those common law principles which accorded with colonial conditions....").

[FN67]. See, e.g, Lany Kramer, The Lawmaking Powers of the Federal Courts, 12 Pace L. Rev. 263,281 (1992) ("The common law was said to be based on principles derived from maxims and customs ... of higher antiquity than memory or history can reach.' These principles were not made byjudges, but were forged through practice and tradition and 'discovered' by the judges who fonnally articulated them.) (quoting 1 Sir William Blackstone, Commentaries on the Laws of England \$ 3, at 67 (Univ. of Chicago Press 1979) (1765)).

[FN68], Manuscript Notes of Senator Pierce Butler (une 23, 1789) (unpublished manuscript contained in the Pietce Butler Papers, onfle with the Pennsylvania Historical Society), quoted in William Casto, The Evie Doctrine and the Structure of Constitutional Revolutions, 62 Tul. L. Rev.907,937 (1988).

[FN69]. For a discussion of Blackstone'sinfluence on the Revolutionary Generation, see Dennis R. Nolan, Sir Wilitiam Blackstone and the New American Republic: A Study of Intellectual Impact, 51 N.Y.U.L. Rev. 731, 747 (1976). See also Casto, supranote 68, at914 ("The English colonists brought the common law with them to America, and the sheer elegance, wonderful organization, and virtual monopoly of the Commentaries made Blackstone's work an unquestioned paradigm for early American attomeys."); Ritz, supra note 42, at 32 ("The single English work that was most familiar to Americans in $1787-89$ must have been Blackstone's Conmentaries.").

[FN70]. 1 Sir William Blackstone, Commentaries on the Laws of England 108 (Univ. of Chicago Press 1979). ("Such colonistscarty with them only so much of the English law, as is applicable to their own situation and the condition of an infant colony.... (A) multitude of... provisions are neithernecessary0 nor convenient for them, and therefore are not in force."). James Wilson, a framer of the United States Constitution and later an Associate Justice of the United State Supreme Court, cited Blackstone with approvalon thispointin his lectures on law James Wilson, The Works of James Wilson 529 (James DeWitt Andrews ed., Callaghan and Company 1896); see Shannon C. Stimson, The American Revolution in Law 129 (1990) (discussing Wilson's views on the differences between English and American law).

[FN71]. See Morton]. Horwitz, Foreword: The Constitution of Change: Legal Fundamentality Without Fundamentalism, 107Harv. L. Rev. 30, 48 -49 (1993) (arguing that while the commonlaw was viewed in England as capable of evolution by the time of the American Revolution, American lawyers of the Framers' day were "firmly wedded" to "Whig oniginalism"). Professor Horwitz further noted that 
"Whig doctrine was ... dependent primarily on static conceptions either of an ancient constitution derived from immemorial custom or of a long past Anglo-Saxongolden age that provided the standard by which the common law could return to its original purity."Id, at 45; see also Stimson, supranote 70 , at 77 ("C) olonial lawyers such as (John) Adams persisted in supporting their legal arguments by reference to the 'general principles' of Englishmen's common law rights, rather than resort to the technical 'niceties' of that law....").

[FN72], The Reexamination Clause as originallyproposed provided: "(N)or shall any fact tiable byjury, according to the course of common law, be otherwise re-examinable than may consist with the principles of commonlaw." See Coebel, supta note 43, at 431 (quoting I Annals of Congress 452). The substitution of "rules" for "principles" in the Clause was not explained.

[FN73]. See Kramer, supranote 67, at 281-82 ("The task of a common law courtwas... tomold these principles to the exigencies of the day, to preserve their essence by fitting them to evolving social customs...."). To the extent commonlaw rules were viewed as fixed and deterninate by the Revolutionary Generation, this characterization may have reflected the fact that the law had changed very slowly in mid-eighteenthcenrury America. See Nelson, supra note 65, at 19. Professor Nelson has written:

Men who were practicing law in the 1760 s, unlike lawyers of today, did not witness the courts handing down decisions that frequently modifed-either explicitly or implicitly-existinglaw or otherwise made new law .... Nor could mid-eighteenth century lawyers remember a period when law had changed rapidly as a result of statute orjudicial decision; the last such period in Massachusetts had been at the beginnirg of the eighteenth century.

Id.

[FN74]. See, e.g., Albert W. Alschuler, Rediscovering Blackstone, 145 U.Pa. L. Rev. 1,37-43 (1996) (arguing that Blackstone understood that the common law had changedover time and would continue to doso); Wolfram, supra note 16, at 736 n.289 (noting Blackstone's image of the common law as an English castle made over into a more modern house).

[FN75], For ageneral discussion of Lord Mansfield's time on the King's Bench, seeC.H.S. Fifoot, LordMansfield46, 118 (1936); Edmund Heward, LordMansfield 45-64,99-110,176 (1979).

[FN76]. Charge to the Grand]ury for the District of Massachusetts (June 7, 1793), reprinted in Federal Gazette (Philadelphia), June 25, 1793, quoted in Stewart Jay, Origins of Federal Common Law: Part Two, 133U.Pa. L. Rev. 1231, 1237 (1985).

[FN77]. Horwitz, supra note 65, at 18; see also Forrest McDonald, Novus Ordo Seclorum 85 (1985) ("Judges were what Americans distrusted, and Mansfield was one of the reasons for this distrust.").

[FN78]. See Horwiz, supra note 65, at 18 ("No period of English law of whatever length it be taken, can be produced wherein so many of it's (sic) settled rules have been reversed as during the time of (LordMansfield)."') (quoting Jefferson). 
[FN79]. See supranote 54 and accompanyingtext (noting the lack oflegislative history concerning the Reexamination Clause).

[FN80]. See Horwitz, supra note 65, at 18 ("What underlay these demands for codification was anew conviction that much of the English common law itself was a product of the whim of judges.").

[FN81]. See supta note 56 (noting that the method for reviewing common-law judgments was the writ of error). The Judiciary Act of 1789 adopted the writ as the method of review for common-law judgments. Judiciary Act of 1789 , ch. $20 \$ \$ 22,25 ; 1$ Stat. 73 .

[FN82]. CE Honwitz, supranote 65, at 18 (noting that in his work on the codification of Virginia law, Jefferson was "prepared to limit common law reception torules existing in the thirteenthcentury, if not before!").

[FN83]. Wolfram, supranote 16, at 725 n.248 (citingRobert Allen Rutland, BirthofBill of Rights $1776-1791$, at $191,198(1955))$.

[FN84]. Indeed, the evidence indicates that the Federalist]ames Madison was the driving force behind the Bill of Rights. As Professor Rakove has explained:

By the time the First Congress mustered a quonum in April 1789, it was not evident that action on amendments was imperative. Most Federalists had grown indifferent to the question, nor were former Anti-Federalists now sittingin Congress any more insistent, largely because they knew that the substancive changes they desited in the Constitution lay beyond their reach. Nearly all Madison's colleagues in Congress thought the entre subject could be deferred... But Madison insisted that Congress had to act sooner, not later, and the amendments it eventually submitted to the states in September 1789 followed closely the proposals he introduced in June. Madison was not merely one participant amongmanyoreven primus interpares; he was the key acto:

Rakove, supra note 45, at 330-31; see also id at 330 "'Conurary to the usual story, the concessions that Federalist leaders offered to secure ratification in such closely divided states as Massachusetts, Virginia, and New York did notestablish a binding contract to provide a bill of nights.").

[FN85]. See Rakove, supranote 45, at 322-23. Professor Rakove has written:

The most important aspect of the criticismof Article MI, however, was that it located the danger to nights not in the courts per se but in Congress....

...

A bill of rights was required less to guide judges in the administration of justice than to prevent Congress from voiding the common law procedures that Americans venerated.

Id.

[FN86]. The Reexamination Clausemaybesomewhatboader, however, because it wasintended to forbidretrial de novo byjuryon appeal. Such a procedure arguably is consistent with trial by jury. 
[FN87]. See supranotes $25-27$ and accompanyingtext (discussingcases interpreting the Trial-byJury (lause).

[FN88]. See Gasperini v. Center for Humanities, 518 U.S. 415, 432 (1996) ("The Seventh Amendment ... controls the allocation of authority to review verdicts...."); id. at 435 ("(A)ppellate review for abuse of discretion is reconcilable with the Seventh Amendment as a control necessary and proper to the fair administration of justice....").

[FN89]. Seesupra notes 45-56 andaccompanyingtext (discussing the origins of the Reexamination Clause).

[FN90]. The Reexamination Clause cannot plausibly be read to give constitutional status to all current rules of reexamination applicable to facts tried by a jury. As I discuss below, relatively few rules of reexamination are needed to implement the fundamental purpose of the Reexamination Clause, that is, ensuring the proper balance of power between the federaljudiciary and local juries. See infra notes 121 26 and accompanying text (discussing the role of the preclusion doctrine in Reexamination Clause Analysis). For that reason, the Count's long-standing refusal to incorporate matters of detail into the Seventh Amendment has been a wise interpretive strategy. See, c.g., Walkerv. New Mexico \& S. Pac. R.R., 165 U.S. 593, 596 (1897) (holding that the Seventh Amendment "aim is not to preserve mere matters of form and ptocedure butsulastance of right").

[FN91]. See supranotes 37-38 and accompanying text (noting Gasperini'semphasis on "the fair adminiscration of justice").

[FN92]. See, e.g, In re Paoli, 113 F3d 444, 452 (3d Cir: 1997) ("The Seventh Amendment requires that, when a court bifurcates a case, itmust' divide between separate trials in such a way that the same issue is not reexamined by different juries.") (quoting Inre Rhone-Poulenc Rorer, Inc., 51 F3d 1293, 1303 (7th Gr: 1995)); Archv. American Tobacco Co., 175 FR.D. 469, 486,493-94 (E.D. Pa. 1997) (relying on Castano and Rhone-Poulenc to deny class certification based in part on the Reexamination Clause); Smithv. Brown \& Williamson, 174 FRD.90,96n.7 (W.D.Mo. 1997) (Utilizing a separate jury may also violate the Seventh Amendment because the issues of the parties' relative faultare too intertwined to permitseparation."); EEOCv.McDonnell Douglas Corp.,960ESupp. 203, 204-05 (E.D.Mo. 1996) (citing Rhone-Poulenc on reexamination).

[FN93]. Althoughmy discussion focuses on Rhone-Poulenc and Castano, these mass tort cases were not the first to analyze bifurcation using concepts derived from the Reexamination Clause. The Fifth Circuit has been the most consistent in holding that separate trials of overlapping issues violates principles underlying the Reexamination Clause, beginning with its seminal decision in Alabamav Blue Bird Body Co., 573 F.2d 309, 318-19 (5 th Cir 1978). There, the Fifth Circuit, purporting to rely on the Supreme Court's decision in Gasoline Products v. Champlin, 283 U.S. 494 (1931), held that the Seventh Amendment "limitation on the use of bifurcation is a recognition of the fact that inherentin the Seventh Amendment guarantee of a trial by jury is the general right of a litigant to have only one jury pass on a 
common issue of fact."'McDaniel v. Anheuser-Busch, Inc., 987 F.2d 298, 305 (5th Cir. 1993) (quoting Blue Bird, 573 F2dat 318-19) (emphasis added); see also Greenhaw v. Lubbock County Beverage Ass'n, $721 \mathrm{~F} 2 \mathrm{~d} 1019,1025$ (5th Cir 1983) ("That inght tojury trial includes the right to have a single issue decided one time by a single jury.").

The Fifth Circuitstated in McDaniel that "( $t$ )his rule has an additional, pragmatic basis-if two juies were allowed to pass on an issue involving the same factual and legal elements, the verdicts rendered by those juriescould be inconsistent, producing intolerably anomalous results." 987 F2 dat 305 (citing Blue Bird, 573 F2dat 318); see also Blue Bird, 573 F.2dat 318 (opining that Gasoline Products'sinsistence that issues be "separable" was "dictated for the very practical reason that ifseparate juries are allowed to pass on issues involving overlapping legal and factual questions the verdicts rendered by each jury could be inconsisten "); In re Plywood Antitrust Litig., 655 F2d627,636 (5th Cir 1981) (quoting Blue Bird, 573 F.2d at 318),

The Fifth Circuitcases discussed in this footnote anbiguously refer to the "guarantee of a tial by jury," Blue Bird, 573 F.2 dat 318, or the "right to a jury trial," Greenhaw, 221 F.2d at 1025, and do not specifically cite to the Reexamination Clause. The reason for this ambivalence may be that Gasoline Products never refers to reexamination. The supposed "right" to have only one jury pass on a common issue of fact, however; clearly implicates the scope of lawful reexamination of facts tried by ajury.

[FN94]. Inre Rhone-Poulenc Rorer; Inc., 51 F3a1 1293, 1294 (7th Cis: 1995)

[FN95]. Id.

[FN96]. Wadleigh v. Rhone-Poulenc Rore, Inc, 157FR.D.410,424 (N.D. Ill. 1994).

[FN97]. Rhone-Poulenc, 51 F3dat 1303. Insupport of its holding, the Seventh Circuit cited the Supreme Court's decision in Gasoline Products and the Fifth Circuit's decisions in McDaniel and Blue Bird. As I argue below, Gasoline Products provides no support for a reexamination analysis. See in fra Part III.D (discussing Gasoline Products).

[FN98]. Rhone-Poulenc, 51 F3dat 1303. The court also noted that the issues of negligenceand proximate cause overlapped. Referring to the plaintiff' theory that defendants were liable for failing to protect their products from contamination by $\mathrm{Hepatitis} \mathrm{B}$, an omission that also rendered the product susceptible to HIV, the court wrote: "A second or subsequentjury might find that the defendants' failure to take precautions against infection with Hepatitis could not be thought the proximate cause of plaintiffs" infection with $H I V$, a different and unknown bloodbome virus." Id. at 1303.

[FN99].Id.

[FN100]. The court did not consider whether, as a practical matter, there was any real possibility that plainliffs could be found comparatively negligent for using defendants' blood products. 
[FN101]. See Victor E. Schwartz, ComparativeNegligence $§ 17-1$ (1994) (describing howjuries in most comparative negligence systems must apportion fault between the two parties, raising issues as to defendant's fault).

[FN102]. See infra notes 191-94 and accompanying text (suggesting that a second jury could be limited to the comparative negligence question but be presented with the firstjury's theory of negligence).

[FN103]. To simplify the analysis, I focus primarily on the negligence/comparative negligence paradigm. Negligence and proximate cause also overlap, as do other issues in the law. For an excellent discussion of this latter point grounded in products liablility law, see generally]ames A. Henderson Jretal, Optimal Lssue Separation in Modern Products Liability Litigation, 73 Tex. L. Rev. 1653 (1995).

[FN104]. See Albert P. Bedecanré, Rule 42(b) Bifurcation at an Extreme: Polyfurcation of Liabjility Issuesin Environmental Tort Cases, 17 BC. Envt. Aff. L. Rev. 123, 163 (1989) (defining "crossover" issues).

[FN105]. Althoughelements of otherclaims were also subject to bifurcation in Castano, the Fifth Circuit's reexamination analysis focused on the negligence claim. Castano v. American Tobacco Co., 84 F3d734, 750-51 (5th Cin: 1996),

[FN106].Id. at 750 .

[FN107]. Id at 751.

[FN108]. See id ("The risk of suchreevaluation is sogreat thatclass treatmentcan hardly be said to be superior to individual adjudication."). In ordet to certify aclass suit under Rule 23(b) (3), a court must find that "aclass action is superior to other available methods for the fair and efficient adjudication of the controversy." Fed. R. Civ.P.23(b) (3).

[FN109]. Castano, 84 Fi3dat 750 ("Another factor weighing heavily in favor of individual trials is the risk that in order to make this class action manageable, the court will be forced to bifurcate issues in violation of the Seventh Amendment.").

[FN110]. Inre Rhone-Poulenc Rorer, Inc, 51 F3d 1293, 1303 (7th Cir 1995) (statingthat judges "must not divide issues between separate trals in such a way that the same issue is reexamined by different juries").

[FN111]. Castano, 84 F3d at 750. Blue Bird, the seminal Fifth Circuit case uses yet another formularion: "only one jury may" pass' on a common issue of fact." Alabama v. Blue Bird Body Co., 573 F.2d309,318 (5th Cir 1978). 
[FN112]. See infra note 116 and accompanying text (defining the terms "examine" and "consider").

[FN113]. See Greenhaw Lubbock County Beverage Ass'n, 721 F:2d 1019, 1025 (5th Cin: 1983) ("That right to jury tial includes the right to have a single issue decided one time by a single jury.").

[FN1 14]. Seeinfra notes 120-26 and accompanying text (discussing the proper role of preclusion doctrine). In approptiate circunstances, a deternination may be given pred lusive effecteven if it has not been incorporated in a final judgment. 18 Whight \& Mille; supra note 36, \$ 4434; cf. Rhone-Poulenc, 51 F3dat 1303 (noting that ajury verdict may be given predlusive effect to avoid reexamination by another jury).

[FN115]. Because there is always a "risk" that a jury will ignore its instructions, including an instruction to give aprevious finding preclusive effect, Rhone-Poulenc and Castano presumably should not be read to mean that any risk of reexamination gives tise to a constitutional violation. I assume the decisions focus on the heightened risk of inconsistency inherent in a tialstrucure that gives a second jury information needed to reach an independent conclusion about an issue decided authoritatively by an earlier jury.

[FN116].SeeMeriam-Webter'sCollegiate Dictionary 403 (10thed. 1993) (defining "exanine" as meaning "to inquire into carefully: investigate"); id. at 246 (defining "consider" as meaning "to think of es(pecially) with regard to taking some action') .

[FN117]. See infra notes 191-94 and accompanying text (explaining why a subsequent case concerning only comparative negligence must include presentation of the evidence and theories of negligence adopted by the previous jury) .

[FN118].See Note, Original Separate Trials on Issues of Damages and Liability, 48 Va. L. Rev.99, 101.02 (1962) ("Seldom were the issues concerning the basicelements of plaintiff's case suchas defendant's liability and consequent damages split into two separate suits at common law:").

[FN119].283U.S. 494 (1931).

[FN120].U.S. Const. amend. VII, cl.2.

[FN121]. See, e.g., Allan D. Vestal, Res Judicata/Preclusion 429-60 (1969) (noting that constitutional doctrines of full fairh and credit, due process, right tojury trial, and equal protection affect preclusion doctine); 18 Wright \&Miller, supra note $36, \S 4403$ (discussing the policies and sources of res judicata).

[FN122] . Because the Supreme Court's original jurisdiction is limited, see U.S. Const. att. III, § 2,cl. 2 (giving the Supreme Court onginal jurisdiction only in "all cases affecring Ambassadors, other 
Public Ministers and Consults, and those in which a State shall bea Party...."), nules of predu usion are not needed to prevent the Supreme Court from circumventinglimitations on the scope of appellate review. The Reexamination Clause, however, is not directed solely at the Supreme Court. Concern about reexmination during the ratification debates focused on the Supreme Cout rather than inferior federal courts. See supra notes 49-53 and accompanyingtext (discussing the Anti-Federalists' concern about retrials in the Supreme Court). But the Reexarninacion Clause applies to "any court of the United Stares." U.S. Const. amend. VIL, cl. 2. Because Congress may grant inferior federal courts concurrent jurisdiction withstate courts, U.S. Const. art: III, $\S 2$, cl. 1, the Reexamination Clause must require that some rules of preclusion be respected if the Clause is to achieve its purposes. The Full Faith and CreditClause provides no assistance because that Clause does notbind the federal courts. See U.S. Const art. IV, 1 ("Full faich and credit shall be given ineach State to the public Acts, Records, andjudicial Proceedings of everyother State.").

[FN123]. See Restatement (Second) of Judgments $§ 27$ (1980) ("When an issue of factor law is actually litigated and determined by valid and final judgment, and the determination is essential to the judgment, the deternination is condusive in a subsequent action between the parties, whether on the same or a different claim."); Friedenthal et al, supra note 16, at 610 ("An issue is precluded by direct estoppel when the priorjudgment invoked as an estoppel and the present suit are both on the same cause of action."). I recognize that the constitutional boundaries of direct estoppel depend in large part on how broadly the conceptof "same cause of action" is understood. Thispotentiallynettlesome issue need not be addressed here because no matter how nartowly the terms are defined, the same cause of action will always be implicated in both phases of a bifurcated proceeding.

[FN124]. See Friedenthal etal, supra note 16, at 611 ("Since subsequent suits on claims that already have been decided usually are extinguishedentirely by res judicata, examples of direct estoppel are veryfew.").

[FN125].] ]udge Posner in Rhone.Poulenc appears to assume that the results of an issue class would have collaterat rather than direct estopiel effect. See Inre Rhone-Poulenc Rore, Inc, 51 F3d 1293, 1297 (7th Cir. 1995) ("If the special verdict found negligence, individual members of the class would then file individual tort suits in state and federal discrict courts around the nation and would use the special verdict, inconjunction with the doctrine of collateral estoppel, toblock relitigation of the issue of nedigence."). It may be more precise to refer to the estoppel as "direct" because a class trial wouldadjudicate apart of eachindividual claim. Later follow-on trials would adjudicate the same claims. Nothing, however, tums on this difference in terminology.

[FN126]. See, e.g, In re Lower Lake Erie Iron Ore Antitrust Litig, 998 F.2d1144, 1183 (3d Cir. 1993) ("Since the jury found that Wills had suffered damage to its property by the conspiracy, in order not toviolate the Seventh Amendment, the role of the second jury should have been limited to determining the amount of damages Wills incurred from acts taken in furtherance of the conspiracy."); O' Hagan v: Soto, 565 F.Supp. 422, 428 (S.D.N.Y. 1983) (ordering a second partial retrial on Seventh Amendment grounds because jury in first retrial ignored instuction that it was required, at a minimum, to return an 
award of nominal damages); id. at 429 ("For seventh amendment purposes, this court sees no viable distinction between the case where a court disturbs a jury's findings and where another jury, acting beyond the limited purpose for which it was convened, invades the findings of a firstjury.").

[FN127]. For some purposes, negligence and comparative negligence arguably are part of the same issue because

( $t$ ) he questions regarding the causal negligence of the parties and the apportionment of that causal negligence are not independent of one another, but are integrally related in determiningultimate lability.... And when reached, (the) function (of apportionment) is to give further definition to causal negligence for purposes of imposing liability.

Ferguson v NothemStates PowerCo, 239 NW.2d190, 196 (Minn 1976); cf. Williams v.James, 552 A.2d153, 159 (N.J. 1989) (noting that plainuiff's analysis of negligence and comparative negligence "duears two questions as 'one issue, obscur(ing) the fact that each question involves some factual elements that are different and can be determined separately").

Treatingnegligence and comparative negligence as the "same issue" would be inconsistent with the text and purposes of the Reexamination Clause, however "The Clause applies to "facts," not "issues" tried by a jury. To be sure, when a jury renders a verdict at a high level of generality, there may be no practical distinction between the two. When, for example, a jury finds a defendant not negligent, that finding of fact may fairly preclude assertions of negligence basedon theonies not presented to the jury. Cf Restatement (Second) of Judgments $\$ 27 \mathrm{cmt} . \mathrm{c}$ (1980) (defining the term "issue" for purposes of issue preclusion). It makes no difference that the plaintiff in the first suit argued that the defendant was going too fast and in the second suit argued that the defendant did not have his eyes on the road. But a finding of fact should not be defined to include matters that are not farly within its meaning. A factual finding that a defendant is negligent, for example, simply cannot be read fairly to encompass the issue of comparative negligence. Put another way, that a defendant is negligent implies nothing about whether a plaintiff is comparatively negligent. Moreover, viewing logically related issues like negligence and comparativenegligence as part of the "same issue" wouldnotimplement the purposes of the Reexamination Clause. The Reexamination Clause incorporates only those preclusion rules needed to avoid evasion of limitations on verdictreview. See supranotes 121-126 and accompanying text (noting the limited role of the Reexamination Clause in preclusion doctrine).

[FN128].CS. Benson v. Superior Court Dep't of the Trial Courtof Mass., 663F2d355,360 (1st Cir 1981) (Undilitbecomes evident that the government is attempting toencroach on appellants' nght to be free from doublejeopardy, there is no case or controversy that can be brought before this court.").

[FN129].See, e.g., supra note 126 (citingexamples of cases that provide relief when ajuryignores its instruction to give the finding of an ealier jury preclusive effect). Nor was the rule at common law different. For an historical discussion of the English rules of preclusion at common law, see Vestal, supra note 121, at 28-42; Robert Wyness Millar; The Premises of the Judgment as Res Judicata in Continental and Anglo-American Law, 39 Mich. L. Rev. 238 (1940). 
[FN130]. See supra PartIII.B.1 (discussing the extent to which preclusion rules are incorporated in the Reexamination Clause).

[FN131]. Inre Rhone-Poulenc Rorer, Inc, 51 F3d 1293, 1301 (7th Cir: 1995).

[FN132]. Anumber offederal andstate courts have followed this kind of procedure in comparative negligence cases. See infra notes 191-94 and accompanying text (discussing cases where a retrial was limited to the comparative negligence issue and thejury was allowed to hear evidence on the negligence issue).

[FN133]. For discussion of this issue, see infranotes 191-94 and accompanying text.

[FN134].See]. Alexander Tanford, The Law and Psychology of] ury Instructions, 69 Neb. L. Rev. 71 (1990) (examiningjuryresponses to instructions given byjudges).

[RN135].Id at 79-80.

[FN136]. See, e.g, Richardsonv. Marsh, 481 U.S. 200,206 (1987) (noting"the almostinvariable assumption of the law that jurors follow theirinstructions"); Tennesseev. Street, 471 U.S. 409, 415 (1985) (endorsing the "crucial assumption' ... that the jurors followed 'the instructions given them by the trial judge"') (quoting Marshallv. Lonberger, 459 U.S. 422,438 n.6 (1983) (citations omitted)).

[FN137].481U.S.200(1987).

[FN138]. Id. at207 (quotingBrutonv.UnitedStates, 391 U.S. 123, 135-36 (1968)).

[FN139]. See Bruton, 391 U.S. at 137 ("Despite the concededly clear insuuctions to the jury to disregard (codefendant's) inadmissible hearsay evidence inculpating petitioner, ... we cannot accept limiting instuctions as an adequate sulstitute for petitioner's constitutional night of cross-examination."); Jackson v. Denno, 378 US. 368 (1964) (holding that voluntariness of a confession by a criminal defendant cannot be left to the jury to determine in the first instance); cf. Gacy v. Welborn, $994 \mathrm{~F} 2 \mathrm{~d} 305$ (7th Cir 1993) (refusingina death penaltycase to permitempirical challenge to comprehensibility of jury instuctions on the ground that ajury is presumed to inderstand and follow its instructions).

[FN140]. Tanford, supranote 134, at 76-77.

[FN141]. See supra notes 133-35 and accompanying text (arguing that there is no reason to believe ajury would disregard a court instruction about a prior jury's findings than other instructions given by the same court).

[FN142]. The Califonia Supreme Courthas commented in this vein: "(W) cannot assume that a juror willignore hisswornduties. It is more proper to assume that when ajuror is outvoted on an issue 
... he will accept the outcome and continue to deliberate withother jurors honestly and conscientiously to decide the remainingissues." Juarezv. Superior Court of Los Angeles County, 647 P2d 128, 133 (Cal. 1982) (quoting Wardv. Weekes, 258 A.2d 379, 381 (N... Super. Ct. App. Div. 1969)); see also Williamisv. James, 552 A.2d 153, 159 (N.J. 1989) (noting, in circumstances similar to those in Juarez, "the capacity of jurors toengage infair and honest deliberationsnotwithstanding inconsistent positions even as to facts that are identical"). The task faced by such jurors is far more difficult than that faced by later juies in bifurcated proceedings. Jurors in those proceedings can beinstucted that defendant was negligent before they have had an opportunity to form an opinion on the matter: Cf. Juarez, 647 P.2dat 136 (Richardson, J., dissenting) ("()t does notseem to me realistic to assume that a juror who concludes that a party is not culpable would be able conscientiously to apportion financial responsibility to that party."); Willatms, 552 A.2dat 161 (CliffordJ., dissenting) (criticizing the court's rule as tequiring "mental gyrations").

[FN143]. To the extent the Fifth and Seventh Circuits rely on the preclusion rationale, it is unclear why defendants should have standing to challenge certification of an issue class based on the Reexamination Clause. Because there is no second phase to the litigation when the defendant wins the class rial, it is plainiffs-not defendants-who typically should have reason to be concemed that alaterjuty may ignore its instructions. A plaintiff might conceivably win the class trial only to have a later jury improperly nullify the first jury's verdict. By contrast, if the defendant wins the class rial, a later jury will never have the opportunity to nullify the defendant's victory. A more complete analysis of the standing issue is beyond the scope of this paper.

[FN144]. See Jamesetal, stuta note 22, at 388 ("There is general agreement that the mental processes of jurors will not be investigated, nor the effect of those processes on the decision"); see also Fed. R Evid, 606(b) ("Upon an inquiry into the validiry of a verdict or indictment, ajuror may not restify as to any matter or statement occurning during the course of the jury's deliberations or to the effect of anything upon that or any otherjuror's mind or emotions as influencing the jury to assent or dissent from the verdict or indictment or concerning the juror's mental processes in connection therewith....").

[FN145]. See Baltimore \& Caroline Line, Inc. v. Redman, 295 U.S. 654, 657 (1935) ("The (Seventh) Amendment not only preserves (the) right (to jury trial,) but discloses a studied purpose to protect it from indirect impaiment through possible enlargements of the power of reexxamination existing under the commonlaw.").

[FN146]. To simplify the discussion, lassume that the Seventh Amendmentrequires a manimous verdict. See Friedenthal etal., supra note 16, at 528-30 (noting that whether the Seventh Amendment still requires a unanimous verdict has not been decided). A unanimity requirement, however, is not essential to my argument. The argumenteasily can be refomulated to grant litigants the right to a verdict based on the reasoning of the requisite number of jurors needed to reach a verdict.

[FN147]. Butsee infranote 155 (describingan instance in which differences in reasoningamong jurorsmaymatter). 
[FN148].CEChicago \& N.W.Ry v. Dunleavy,22N.E. 15, 18(II. 1889) ("Howevernatual the curiosity parties may have to know the precise course of teasoning by which jurots may arrive at verdicts either for or against them, they have no right ... to require them to give their views upon each item of evidence, and thus practically subject them to a cross-examination as to the entire case."); Holden v. Missouti Pac. R.R, 84S.W.133, 138 (Mo. App. 1904) ("Theaction was basedonnegligence, noton the way in which it was committed").

[FN149]. The Illinois Supreme Court explained the reasons for not requiring unanimity of reasoningas follows:

The common lawrequires that verdicts shall be the declaration of the unanimous judgment of the 12 jurors. Upon all matters which they are required to find, they must be agreed. But it has never been held that they must all reach their conclusions in the same way and by the same method of reasoning.

Dunleavy,22 N.E. at 17; scealso Arkansas M.R.Co. v.Canman, 13S.W.280, 282 (Ark. 1890) ("It is not necessary that a jury ... concur in a single view of a transaction or occurrence disclosed by the evidence."); Stoner v. Williams, 54 Cal. Rptr. 2d243,252 (C. App. 1996) ("(W)e conclude that jurors need notagree from amonga number of alternative acts which act is proved, solong as the jurots agree that each element of the cause of action is proved."); Ipsen v. Ruess, 41 N.W.2d 658, 664 (lowa 1950) ("Unanimity of the conclusion ... is all that is tequired"); Clevelandv. Wong, 701 P.2 1 1301, 1309 (Kan 1985) ("Unanimity upon the specific negligent act or omission is not tequired.") (overruling Barkerv. Railway, 132 P.156 (Kan. 1913)); Brogan v. Union Traction Co, 86 S.E. 753,756 (W.Va. 1915) ("While jurors must all agree upon all matters which they are required to find, they are not required to reach their conclusions by the same method of reasoning."). But see Parrott v. Thacher, 26 Mass. (1 Pick.) 426,43132 (Mass. 1830) ("(D) fitappears that (the jurors) did notagree upon either of the grounds, I donot see how their verdict can stand, unarimity being tequired."); Russell v. Oregon R. \& Navigation Co., 102 P.619, 624 (Or. 1909) (citing Parrott for the proposition that "agood verdict should be based upon some grom upon which all the jurors agree"). See generally, Hayden]. Trubitt, Patchwork Verdicts, Different-Jurors Verdicts, and American Jury Theory: Whether Verdicts Are Invalidated by Juror Disagreement on Issues, 36 Okla. L. Rev. 473, 516-23 (1983) (discussing case law addressing patchwork verdicts).

[FN150].501U.S.624(1991).

[FN151].1d. at631-32 (plurality opinion) (quoting McKoyv. North Carolina, 494 U.S.433, 449 (1990) (Blackmun, J., concurting)); $\mathrm{cf}$ id at 649 (Scalia, ], concurting) ("As the plurality observes, it has long been the general rule that when a single crime can be committed in various ways, jurors need not agree upon the mode of commission.").

[FN152].See Condliff v.Zucker, 336 F. Supp.921,922 (W.D. Pa. 1972) (holding that general verdict was valideven though some jurors found for defendant on ground that defendant was not negligent and others had done so on the ground that plaintiff was contributorily negligent).

[FN153]. See Edward]. Devittetal., Federal Jury Practice and Instructions (4thed, 1992). 
[FN154].See RuthB. Ginsburg, Special Findings and Juty Unanimity in the Federal Countis, 65 Colum L. Rev.256, 268 (1965) ("If each juror sulscribes to at least one of the independent particulars, but no particular is sulbscribed to by all, it seems improbable that the jury would-and out of tune with commonsense notions of justice that the jury should-reportitself "hung rather than proceed to decision.").

[FN155]. It seems clear that some differences in reasoning may be unacceptable. See, e.g., Trubitt, supranote 149, at 514 "Ifplaintiffbrings actions in libel and false imprisonment, and six jurors think heshould recover for libel and theother six for false imprisonment, surely plaintiffshouldrecovernothing."). As apractical matter this sort of problem does not arise in the context of an issue class because juries return special verdicts. For that reason, I have focused on the sort of case likely to arise in an issue class: whether, for example, jurors may rely on different understandings of defendant's negligence to find for the plainiff.

[FN156]. It could be argued that Gasoline Products held otherwise. I discuss and reject as unpersuasive this reading of Gasoline Products in my discussion of the case. See infra notes 195-202 and accompanying rext.

[FN157].See infra Part III.D.2 (discussing what Gasoline Products requires).

[FN158].See Chicago \&N.W.Ry.v. Dunleavy,22N.E. 15, 18 (111. 1889) (noting that the use of very detailed special verdicts would "tend to embarrass and obstruct the administration of justice").

[FN159].See supra notes 120-26 and accompanying text (discussing the extent to which the Reexamination Clause incorporates rules of preclusion).

[FN160]. See discussion infra Part III.D.2 (advocating, in light of Gasoline Products, a structure under which the separate trials of overlapping issues may properly occur).

[FN161]. See infret notes 191-94 and accompanyingtext (noting the necessity that a secondjury hear evidence about the negligence issue in the previous proceeding).

[FN162]. As a practical matter; acceptance of this view most likely would require a unitary trial. See supra notes 157-58 and accompanying text (arguing that requiring a special verdict disclosing first jury's reasoning in full would be impractical).

[FN163]. See supra Part III.B.1 (discussing the extent to which the Reexamination Clause incorporates the rules of preclusion).

[FN164]. Cf Laurence H. Tribe, Taking Text and Structure Seriously: Reflections on Free-Form Methodin Constitutional Interpretation, 108 Harv. L Rev. 1221, 124748 (1995) ("Thusone might... tead requinements like that of 'equal protection of the laws' as refening to general principles that call for elaboration over time in a way that... perhaps ever1... some highly specific rights-protectingprovisions such as, for example, the Seventh Amendment cannot be read ...."). 
[FN165]. As I discuss above, separate trals of overlappingissues donotimplicate finality concerns in a constitutionally meaningful way. See supra notes 128-56 and accompanying text.

[FN166].603 F2d590 (7th Cir: 1979).

[FN167]. Id. at597 (quotingUnited States v. American HondaMotor Co., 273 ESupp.810,820 (N.D. I1. 1967)). In Continental Can, the Seventh Circuitupheld an injunction batring the Secretary of Labor fromprosecuting certain OSHA violations against the company. The appeals court concluded that the refusal of the Occupational Safety and Health Review Commission to apply collateral estoppel constitured haressment in violation of the Due Process Clause. While the characterization of the conduct atissue as harassment provides a firm basis for liniling the case to instances where an improper governmental motive can be shown, the language quoted in the text can be read more broadly to forbid imposition of constitutionally unreasonable litigation burdens by any state actor.

[FN168]. Such a standard would not necessarily be enforceable only under the Due Process Clause. The Courthas treated other Clauses in the Constitutionas addressing concems parallel to those addressed by the Due Process Clause. See, e.g., Phillips Petroleum Co. v. Shutts, 472 U.S. 797, 818-19 (1985) (stating that the Full Faith and Creditand Due Process Clauses impose the same constitutional requirements onchoice oflaw).

[FN169]. See, e.g, Castanov, American Tobacco Co, 84 F3d734, 749 (5thCir: 1996) ("Itmay be that comparative negligence will be raised in the individual trials, and the evidence presented at the class trial will have to be repeated... The net result may be a waste, not a savings, of judicial resources."); see also Bedecarré, supra note 104, at 163-64 (arguing that bifurcation "should not be ordered when there are significantcross-over issues thatmust be retried in laterphases."). Butseeinfranote 172 and accompanying text (noting that bifurcation may serve judicial economy even when crossover issues must be reheard).

[FN170]. When ageneralverdict is rendered for a defendant, it may be impossible to determine the basis of the verdict. In an action for trespass, for example, ageneral verdict would notreveal that the jury found for the defendant because the plaintiff did not have lawful possession of the property. For that reason, if the plaintiff were to bring stit against a defendant based on another alleged act of trespass, ownership would have to be relitigated all over again.

[FN171].See, e.g, Peabody Coal Co.v. Spese, 117 Fi3d1001, 1007 (7th Cir. 1997) ("(H) ddings in the altemative, either of which would independentlybesufficient to support a result, are notconclusive insubsequent litigation with respect to either issue standing alone."); Bonstv. Chevron Corp., 36 F3d 1308, 1314n.11 (5th Cir: 1994) ("The federal decisions agree that once an appellate court has affirmed on one ground and passed over another, preclusion does not attach to the ground omitted from its decision.") (quoting 18 Wright \& Miller, supranote 36, $\$ 4421$ ). See generally Restatement (Second) of Judgments $\$ 27 \mathrm{~cm} t s .1,0$ (1982) (illustrating alternative deteminations by a court of first instance and the effect of affirmance or reversal of altemative deterninations in an appellate court, respectively). 
[FN172], Similarly, bifurcation mayprove economical if the defendant is able to nanrow the issues bypartially prevailingin the class trial.

[FN173]. Cf. In re Dow Coming, 211 B.R. 545, 584 (Bankr E.D. Mich. 1997) (noting thata victory for plaintiff on the general causation issue "while not dispositive would likely have a favorable impactonsettlementprospects").

[FN174].See In re Copley Pharm., Inc., 161 FR. D. 456,466 (D. Wyo. 1995) ("(T)opernit the defendant to contest liability with each claimant in a single separate suit would, in many cases, give defendants an advantage which would almost be equivalent to closing the door of justice to small claimants.) (quoting Weeks v. Bareco Oil Co., 125 F.2d84, 90 (7th Cir, 1941)); David Rosenberg, Class Actions for Mass Torrs: DoingIndividual Justice by Collective Means, 62 Ind. L.J. 561, 570 (1987) ("(T) he case-by-case, individualized processing of the mass tortclaims that are fited confers a strategic edge upon defendant firms."); id. at 571 (describing the strategic advantages enjoyed by defendants); Johnson, supranote 7, at 2368 ("Defendants... may spread their litigation casts over the entire class of mass product liability claims.').

[FN175]. The Castanocourt noted thatother means may be used to achieve collective action. The court suggested, for example, that "(t)he class is represented by a consortium of well-financed plaintiff' lawyers who, over time, can develop the expertise and specialized knowledge to beat the tobaccocompanies at their own game." Castanov. American Tobacco Co., 84 F3d734, 747 n.25 (5thCir: 1995) (emphasis added). This approach unjustifiably sacrifices the interests of early plaintiffs. The court mone persuasively suggested that "(c) ourts can also overcome the defendant's alleged advantages through coordination or consolidation of cases for discovery and other pretrial matters." Id. It seems dear, however, that the class suit provides the more effective means for overconing a defendant's strategic advantage. Consolidation and coordination can be used only with respect to cases alreacty in federal court. The class device sweeps more buadly, simultaneoushy providing the benefits of aggregation to those who have not yet filed suit and creating a largerfinancial base for the plaintiffs' side.

[FN176], Butcf. In re AmericanMed. Sys., Inc., 75F3d1069, 1087 (6th Cin. 1996) (finding that trial court'srecogrition of defendants' strategic edge as a basis for certification constituted an impermissibly "strong bias in favor of class certification").

[FN177]. SeeParklane Hosiery Co. v.Shore, 439U.S.322, 329-31 (1979) (discussingrequirenents for use of offensive collateral estoppel).

[FN178]. See Jack Ratliff, Offensive Collateral Estoppel and the Option Effect, 67 Tex. L. Rev.63, 89 (1988) ("Although most practitioners understand that some feature of the case that is supposedly "irrelevan' to liability-the severity of plaintiff s injuries, for example-may weil determine liability in a close case, the tulesgoverning collateral estoppel take no account of the phenomenon."); id at91 (noting that anun likely will receive a more sympathetic hearing from a jury in a negligence case than a convict). 
[FN179].Id. at 89-90 (noting that class actions "generally avoid the spillover effect by requiring that the claim be 'typical' and the plainifff fairly representative of the class"). Use of the class device or some other means of aggregation may also focus the jury's attention on the broad impact that its verdict will have.

[FN180]. The risk of nonmutual offensive collateral estoppel is rather low for most mass tort defendants in part because issue preclusion is avalable to a plaintiff only if there are no judgments on the identical issue in favor of the defendant. See Parklane, 439 U.S. at 330 ("Allowing offensive collateral estoppel may also be unfair to a defendant if the judgment relied upon as a basis for the estoppel is itself inconsistent with one or more previousjudgments infavor of the defendant."); Hardyv. Johns-Manville Sales Corp., 681 F2d 334, 345 46 (5th Cir. 1982) (concluding that inconsistent verdicts make offensive collateral estoppel inappropriate). The odds are strongly in favor of mass tort defendants in early cases. As Professor McGovem has noted:

The cyclical theory of mass tort litigation contemplates an initial stage in the litigation during which there are inherent advantages for the defendant... . During this initial stage of the cycle, the defendant tends to win the cases itchooses to tyyand is oftenable to settle lawsuits quietly with little impact onother cases.

Francis E. McGovem, An Analysisof Mass Torts forJudges, 73 Tex. L. Rev, 1821, 1842 (1995). For an overview of the difficulties of applying issue predusion in mass tort cases, see Linda S. Mullenix, Mass TortLitigation: Casesand Materials 415-38 (1996).

[N181], SeeInreRhone-Poulenc Rore, Inc, 51 F3d 1293, 1303 (7th Cir 1995) (citingGasoline Products in support of the proposition that separate trials of overlapping issues would violate the Seventh Amendment); Castano v. American Tobacco Co., 84 F3d 734, 750 (5th Cir. 1996) (citing Gasoline Products for the proposition that the issues must be distinct and separable to allow bifurcation). Although Gasoline Products considered the scope of anew tial on remand, see infra notes 183-85 andaccompanying text, it is commonly understood that the reasoning of the case applies to bifurcation as well. 9 Whight \& Miller supra note $36, \$ 2391$, at 514 .

[FN182], If Gasoline Products held that ovelapping issues could not be tried separacely, the Reexamination Clatse would seem to be the only available rationale for such a holding in light of the fact that the Gasoline Products Court specifically rejected the view that the Seventh Amendment always requires the unitary trial of a cause of action. Gasoline Prods. Co. v. Champlin Ref. Co., 283 U.S. 494, 49899 (1931).

[FN183]. Id. at 498. By rejecting the raditional rule that erroneous verdicts must be set aside in theirentinety, the Court eliminated reexamination of issues that had been conectly decided. The Court; however, did notopine that this result was compelled by the Reexamination Olause, butsimply concluded that the Seventh Amendment does not "require that an issue once contectly determined... be tried a second time."Id. 
[FN184], ]d. at 500 .

[FN185]. Id.; see also Gasoline Prods, 283U.S. at500 ("Where the practice permits a partial new trial, itmay not properly be resorted to urless itclearly appears that the issue to be retried is so distinct and separable from the others that a tial of it alone nay be had without injustice.").

[FN186]. See, e.g, Castano, 84F3dat 750 (arguing that the "Constiution allows bifurcation of issues that are so separable that a second jury will not be called upon to reconsider findings of fact by the first").

[FN187]. See Brooks v Great Lakes Dredge-Dock Co., 754 F.2d 539, 541 (5th Cir. 1985) (finding, in Jones Act case, that "the issue of contributory negligence is distinct and separable from the issue 0 of (defendan's) negligence. .."). Although cases decided under the Jones Act, 46 U.S.C. app. \& 688 (1994), confusingly refer to "contributory negligence," courts in such cases apply a comparative negligence analysis. See Schwartz, supra nove 101, § 1-4(a) (noting that "Congress incorporated the principle of pure comparative negligence in the Jones Act in 1920"). For other federal cases outside the Fifth Circuit that find negligenceand comparative negligence issues distinct and separable, see Akermanis v.Sea-Land Service, Inc, 688 F2d898 (2dGr 1982) (permitting retrial limited to comparativenegligence); In reNew York Asbestos Litigation, 155 FRD.61 (SD.NY. 1994) (imitingretial toproximate cause and comparative negligence); and compare Warshany v. Supermarkets General Corp., 391 A.2d 1271, 1274 (N.J. Super. Ct. Law Div. 1978) (concluding that "causal negligence and apportionment are 'fairly separable' in the concept of comparative negligence law").

[FN188]. Gasoline Prods.,283U.S. at 500. That "interwoven" issues are not necessarlyoverlapping issues is evident from a close reading of Gasoline Products. Gasoline Products, for example, cites Simmons v. Fish for the proposition that an issue must be separable if it is to be tried separately. Id. (citing Simmons v. Fish, 210Mass. 563 (Mass. 1912)). In Simmons, the Massachusetts Supieme Court had held that a retrial limited to damages could not be ordered when it appeared that the first jury had improperly entered a compromise verdict. Id. at $572-73$. Thus, the lack of separability in Simmons resulted from the possible misconduct of the jury rather than the in herent nature of the issues.

[FN189]. Crane v. Consolidated Rail Corp., 731 F2d 1042, 1049 (2d Cir. 1984) (discussing Gasoline Products); see also id. at 1050 ("Clearly ajury retrying only the issue of comparative faultwould not have faced the insuperable difficulties that would have confronted a jury attempting to try only the issue of damages in the Gasoline Producrs case-the point to which the cautionarylanguage of thatopinion was addressed."); Bedecarré, supra note 104, at 129 ("The (Gasoline Products) Court focused... on avoiding confusion of the trier of fact due to incomplete information.").

[FN190]. Seesupranote 168 (discussingthe Count's treatment of various Clauses in the Constitution as encompassing concerns similar to those of the Due Process Clause). 
[FN191]. See infra Part III.D.2 (advocating special verdict forms toward this end).

[FN192]. See, e.g., Akemanis, 688 F2d at 907 (holding that the trial judge has discretion to narrow retrial to the question of contributory negligence); Trejo v. Denver $\&$ Rio Grande W.R.R, 568F.2d 181 (10th Cin: 1977) (orderinga retrial of the damage issue due to trial cout's enoneous jury instruction); Cromlingv. Pittsburgh \& Lake Erie R.R. Co., 327 F2d 142 (3dCir. 1963) (limiting retrial to the damages issue in the interest of justice).

\section{[FN193].688F2d898 (2dCir 1982).}

[FN194]. The Second Circuitstated:

(T) he jury would be told that defendant's negligence has already been determined and that their lask is only to deternine whether the plaintiff was (comparatively) negligent and, if so, to deternine what percentage of responsibility for the accident is attributable to the plaintiffs (comparative) negligence. The parties would, of course, beentidled to present all evidence relevant to the fault of both parties in order for the jury to make an apportionment of fault.

Id at $907 \mathrm{n} 6$; seealso Trejo, $568 \mathrm{~F} 2 \mathrm{~d}$ at 185 (authorizing asimilar procedure); Cromling $327 \mathrm{~F} 2 \mathrm{~d}$ at 152-53 (same); In re New York Asbestos Litig., 155 FR.D.61,66 (S.D.N.Y. 1994) (limitingnew rial to proximate cause and comparative negligence, but noting that "(b)oth parties will be entitled topresent all evidence relevant to the fault of all adjudged tort-feasors in order for the jury to make an apportionment of (defendan's) faule'); cf. OKelly v. Willig Freight Lines, 136 Cal. Rptr. 171, 173 (Cal. Ct. App. 1977) (granting partial retial limited to the issue of apportionment athough "(i) $\mathrm{t}$ is true that, in order to make a proper allocation of damage, the jury on the new rrial will have to hear, and weigh, anew, all of the evidence dealing with the conduct of the partics..."); Warshanyv. Supermarkets Gen. Corp., 391 A.2d 1271, 1274 (N.J. Super Ct. Law Div. 1978) ("Onretrial, thejury's finding of causal negligencestands, but the parties are permitted to introduce any evidence relevant to a determination of apportionment.") (citing Firkus v. Rombalski, 130 N.W.2d835 (Wis. 1964)); Caldwell v. Piggly.Wiggly MadisonCo., 145 N.W.2d745,752 (Wis. 1966) ("In the retrial of the case.... (t) he finding of causal negligence will stand, but evidence may be introduced for the purpose of detemining the apportionment."). Cf. generally Schwartz, supra note 101, \$17-1.(d) (discussingvarious guidelines for comparison of fault byjuries).

[FN195]. See supranotes 146 and acoompanying text (explaining the argument that alater jury must follow the reasoning of an earlier jury).

[FN196]. See supra note 158 and accompanying text (discussing practical difficulties tesulting from exhaustively detailed special verdicts).

[FN197]. Cf supra text accompanyingnote 157 (arguing that firstjury in bifurcated proceeding need only provide sufficient guidance to second jury to avoid confusion and uncertainty).

[FN198]. Gasoline Prods. Co.v. Champlin Ref. Co., 283U.S.494,499-500 (1931). 
[FN199]. See supranotes 149-55 and accompanyingtext (dixcussingrelevant authority).

[FN200]. I do not mean to suggest that the First Circuit punposefullyentered a retrial order that made it impossible to try the case failly. The First Circuit previously had shown an acute awareness that a partial retrial limited to damages could be unfair:See American Locomotive Co. v. Harris, 239 F2 234, 240 (1stCir: 1917) ("Tojustifyanappellate court in liniting the issues on a new trial to the question of damages, it should clearly appear that all questions in respect to liability have been considered and passed upon by the jury."). A close reading of the First Circuit's decision in Gasoline Products suggests that the First Circuit believed the jury verdict resolved far more than the Supreme Court perceived it resolved. 39 F.2d521 (1930).

[FN201].238U.S.269(1915).

[FN202]. Gasoline Prods, 283U.S. at500 (citing Ferelee for the proposition that " $w$ ) here the practice permits a partial new trial, it may not properly be resorted to unless itclearly appears that the issue to be retuied is so distinct andseparable from the others that a cial of italone may be had without injustice").

In Ferebee, the North Carolina Supreme Court had remanded a case under the Federal Employers' Liability Act ("FELA'), 45 U.S.C. \$ 51 (1994) (amended version of Act of Apr: 22, 1908, ch. $149, \S 1,35$ Stat. 65), for anew trial on damages only. On retrial, the defendantsought to presentevidence thatplaintiff had been negligentin order toneduce the damages award. Ferebee, 238U.S. at 272. The trial coust

refused to submit to the jury the question as to how much should be deducted from the damages sustained because of the plaintiff's contributory negligence, for the reason that the Supreme Court of North Carolina had granted a new trial to assess damages and had thereby excluded the issue of contributorynegligence from the case.

Id. at 272. Although the Cout confusingly referred to "contributory negligence," compararive negligenceprinciples apply in FELA cases. See Schwarz, supta nore 101, \$1-4(a) (noting that the Federal Employers' Liability Act adopted the principles of comparative negligence).

On appeal, the United States Supreme Court concluded:

(D) amages and contributorynegligence are so blended and interwoven, and the conduct of the plaintiff at the time of the accident is so important a matter in the assessment of damages, that the instances would be rare in which it would be proper to submit to a jury the question of damages without also permitting them to consider the conduct of the plaintiff at the time of the inquiry.

Ferebee, 238U.S. at 273. The Supreme Court nonetheless affrmed because the special verdict returned in the first trial had established that Ferebee was nor negligent, "so that it was possible, on the second trial, to award damages without considering the conduct of the plaintiff or retrying the question of contributory negligence." Id. at 273.

[FN203]. The counterclaim defendant could not be required to provide a juy with much guidance in this regard. It is one thing to force a party to accept the formal findings of a previous jury when making arguments to a later jury. It is yet another to expect that party to specify how it might be liable. While tactical considerations in a given case may usually persuade a party to provide that sort of assistance 
to the jury, I see no basis for requiring a party to forego a defense on any matter that has not been detemined by the earlier verdict. Put another way, while a party may be unable to argue that it did not breach the contract in the face of a contrary jury verdict, it is under no obligation to concede any of the specific acts allegedlyconstiouting the breach, unless the verdict identifies the specific breaches.

[FN204]. Cf. Juarez v. Superior Court of Los Angeles County, 647 P.2d 128, 136 (Cal. 1982) (Richardson, J., dissenting) ("His perception of a legal compulsion upon him to affix some responsibility upon a party whom he concludes is notresponsible at all is more likely to cause that juror to assign to such a party an arbitrary proportion of the total hability.").

[FN205]. See supra nores 192-94 and accompanying text (illustrating this point in the context of separate trials of negligence and comparativenegligence issues).

[FN206]. My discussion of Gasoline Products focuses on whether the separate trial of ovetlapping issues inevitably creates a risk of confusion and uncertainty in the second phase of a bifurcated proceeding. Bifurcation may lead to confusion in oher ways. For an impassioned argument that bifurcation of genera! and specific causation in particulatly technical cases may confuse layjurors in the first phase of proceedings, see Bedecarré, supranote 104, at 151-63. The possibility of confusion and uncertainty in the first phase of the litigation is beyond the scope of this paper: 